\title{
Iniciativas institucionais de valorização do patrimônio geológico do Brasil
}

\author{
Institutional programs for the valuation of geological heritage of Brazil \\ KÁTIA LEITE MANSUR ${ }^{1}$, ANTONIO JOSÉ DOURADO ROCHA ${ }^{2}$, AUGUSTO PEDREIRA (in memoriam) ${ }^{2}$, \\ CARLOS SCHOBBENHAUS ${ }^{2}$, EDUARDO SALAMUNI ${ }^{3}$, FLÁVIO DA COSTA ERTHAL ${ }^{4}$, GIL PIEKARZ ${ }^{5}$, \\ MANFREDO WINGE ${ }^{6}$, MARCOS ANTÔNIO LEITE NASCIMENTO ${ }^{7}$, ROGÉRIO RODRIGUES RIBEIRO ${ }^{8}$. \\ ${ }^{1}$ Universidade Federal do Rio de Janeiro - katia@geologia.ufri.br \\ ${ }_{2}^{2}$ Serviço Geológico do Brasil (CPRM) - antonio.dourado@cprm.gov.br - carlos.schobbenhaus@cprm.gov.br \\ ${ }^{3}$ Universidade Federal do Paraná - salamuni@ufpr.br \\ ${ }^{4}$ Serviço Geológico do Estado do Rio de Janeiro (DRM-RJ) - ferthal@drm.rj.gov.br \\ ${ }^{5}$ Serviço Geológico do Paraná (MINEROPAR) - gil.piekarz@gmail.com \\ ${ }^{6}$ Comissão Brasileira de Sítios Geológicos e Paleobiológicos (SIGEP) - mwinge@terra.com.br \\ 7 Universidade Federal do Rio Grande do Norte - marcos@geologia.ufrn.br \\ 8Instituto Geológico de São Paulo (IG) - rrribeiro@igeologico.sp.gov.br
}

\section{Resumo}

O presente artigo tem como objetivo apresentar e discutir as iniciativas para divulgação e popularização do patrimônio geológico do Brasil. São apresentados casos de âmbito nacional, na forma das ações de inventário promovido pela SIGEP e dos projetos Geoparques e Banco de Dados de Geossítios do Brasil da CPRM. No âmbito estadual são apresentadas as experiências dos projetos Caminhos Geológicos do Estado do Rio de Janeiro desenvolvido DRM-RJ, Sítios Geológicos e Paleontológicos do Paraná da MINEROPAR, Caminhos Geológicos da Bahia da CPRM e Petrobras, dos Monumentos Geológicos do Rio Grande do Norte do IDEMA e dos Monumentos Geológicos de São Paulo do IG-SP. Os casos demonstram que existe um amplo espaço para desenvolvimento dos projetos de geoturismo e divulgação do patrimônio geológico para a sociedade e que este espaço vem sendo ocupado pelos serviços geológicos e entidades afins de âmbito estadual, onde a implantação de painéis interpretativos tem sido um dos principais instrumentos utilizados. Fica clara, ainda, a necessidade de que haja uma organização responsável pela implantação e manutenção dos painéis. Considera-se que estes tipos de projetos propiciam a participação comunitária e o desenvolvimento de projetos educacionais. Vislumbra-se que as unidades de conservação são lugares especiais para a implantação deste tipo de sinalização, propiciando a divulgação da geodiversidade em conjunto com a biodiversidade. Por fim, considera-se, ainda, que o maior obstáculo a ser superado é a comunicação com a sociedade. Para tanto, precisa-se avançar no conhecimento sobre o usuário dos painéis interpretativos. É necessária, portanto, a realização de pesquisas sobre o público-alvo e planejamento prévio da interpretação, ou seja, deve-se melhorar cada vez mais a comunicação para despertar o interesse do usuário/visitante.

Palavras-chave: Patrimônio Geológico; Geoconservação; Geoturismo; Divulgação das Geociências.

\section{Abstract}

This paper aims to present and discuss the initiatives for interpretation and popularization of geological heritage of Brazil. National examples are presented in the form of inventory actions promoted by SIGEP and by CPRM projects: Geoparks and Database of Geosites of Brazil. At the State level are presented the experiences of the Geological Paths Project of the State of Rio de Janeiro developed by DRM-RJ; Geological and Paleontological Sites of Paraná by MINEROPAR; Geological Paths of Bahia by CPRM and Petrobras; Geological Monuments of Rio Grande do Norte by IDEMA; and the Geological Monuments of São Paulo by IG-SP. These cases demonstrate that there is a broad space for development of geotourism projects and popularization of geological heritage for society. This space has been occupied by the geological survey and related entities at the State level. The implementation of interpretative panels has been one of the main instruments used. It is clear, though, that is indispensable an organization be responsible for the implementation and maintenance of the panels. It is considered that these types of projects encourage community participation and the development of educational projects. Protected areas are special places for the implementation of this type of signage, enabling the dissemination of geodiversity in conjunction with biodiversity. Finally, it is considered that the biggest hurdle to be overcome is communication with the society. To do so, will need to advance in the knowledge of the user of the interpretative panels. It is necessary, therefore, to carry out research on the target audience and prior planning of interpretation, in other words, it should be increasingly improving communication to user interest.

Keywords: Geological Heritage; Geoconservation; Geotourism; Disclosure of Geosciences. 


\section{INTRODUÇÃO}

\subsection{Histórico}

Iniciativas de divulgação da geologia para a sociedade no Brasil existem há décadas. Confirma esta afirmação a implantação, em 1988, de 17 marcos de concreto com descrição geológica de afloramentos ao longo da Rodovia SC-438, na Serra do Rio do Rastro, em Santa Catarina. Esta sinalização deu visibilidade pública à denominada Coluna White, ou seja, a coluna estratigráfica definida em 1908 no relatório do geólogo Israel White, sobre a borda sudeste da Bacia do Paraná, um representante clássico da história evolutiva do Gondwana (Orlandi Filho et al. 2002).

Outros exemplos, como o Parque do Varvito, em Itu, e o Parque da Rocha Moutonnée, em Salto, ambos no Estado de São Paulo, fundados na década de 1990, promovem a informação geológica, por meio da ampla visitação que recebem (Rocha-Campos, 2002a; 2002b).

A SIGEP - Comissão Brasileira de Sítios Geológicos e Paleobiológicos, criada em 1997 com a missão de organizar o banco de dados nacional, tornou disponível na internet as descrições de geossítios apresentadas pelos pesquisadores e avaliadas no mérito por representantes de instituições brasileiras relacionadas à Geologia. A SIGEP também vem fomentando descrições dos sítios em linguagem popular "com vistas à ampla divulgação das geociências e da mentalidade preservacionista com relação aos nossos monumentos geológicos, promovendo assim, simultaneamente, a popularização das geociências" conforme consta da apresentação da comissão no seu endereço eletrônico (http://sigep.cprm.gov.br/).

Todavia, somente no início do século 21, projetos de divulgação geológica sistemática começaram a ser estruturados no país. Estes projetos vêm proporcionando uma abertura para a inserção da geologia nas comunidades, na sinalização de unidades de conservação e no desenvolvimento de programas educacionais locais. Quase todos baseiam suas iniciativas na confecção de painéis e folhetos interpretativos sobre a evolução geológica de monumentos de importância paisagística, científica e/ou turística e se estruturaram como projetos de âmbito estadual.

\subsection{Popularização da Geologia e Valorização do Patrimônio Geológico: Compromissos e Desafios}

No Brasil, projetos de divulgação científica têm sido cada vez mais comuns, como pode ser avaliado nas edições da Semana Nacional de Ciência e Tecnologia, onde, a cada nova edição, ampliam-se as atividades e a participação popular. Ações relacionadas às áreas de popularização da Física, Medicina, Matemática,
Astronomia, entre outras, vêm despertando grande atenção nos meios escolares o que certamente permitirá, em pouco tempo, seu fácil reconhecimento e entendimento. Um exemplo desta possibilidade de inserção pode ser tomado da Biologia, onde alguns dos seus termos técnicos já compõem o vocabulário do cidadão comum, dado o entendimento da importância do mundo biótico e da necessidade de se manter o planeta sadio. Da mesma forma, espera-se incluir o respeito e atenção ao planeta como um todo, para garantir o espaço de divulgação das Ciências da Terra no conjunto da população.

Os grandes agentes de financiamento de pesquisa em C\&T já possuem linhas para atendimento das demandas na área de popularização da ciência, desde o CNPq Conselho Nacional de Desenvolvimento Científico e Tecnológico até as FAPs - Fundações de Amparo a Pesquisa de âmbito estadual. Neste contexto, a popularização da geologia pode se desenvolver amplamente.

A despeito da repercussão positiva dos projetos de disseminação do conhecimento geológico no Brasil, tanto no meio geológico quanto na sociedade em geral, um desafio tem sido colocado incessantemente para aqueles que trabalham com o tema: adequar a linguagem hermética praticada pelos geólogos para entendimento pelo cidadão comum.

Os modelos de comunicação pública em ciências ainda promovem polêmicas entre os autores que, cada vez mais, buscam uma forma democrática e inclusiva para promover os temas de CTS (Ciência, Tecnologia e Sociedade) para a população (Durant 1999; Moreira e Massarani 2002; Lewenstein \& Brossard 2005; Moreira 2006; Navas et al. 2007; Navas 2008). O modelo mais tradicional, denominado Modelo de Déficit, parte do pressuposto que o cientista precisa aportar seu conhecimento para aqueles grupos que não o possuem, suprindo um déficit de conhecimento. Esta forma de comunicação vem sendo combatida por não levar em conta os saberes tradicionais. Posteriormente, surgiu o Modelo da Participação Pública que estimula a participação e manifestação do conhecimento popular pela participação em fóruns, debates e reuniões, onde público e cientistas têm papéis equivalentes.

A principal forma de comunicação dos projetos de divulgação geológica sistemática no Brasil se dá por meio da implantação de painéis interpretativos (Nascimento et al. 2009). Esta técnica é utilizada em muitos países (Hose 1997, 2000, 2008; Dias et al. 2003; Carter 2001). A comunicação também pode ser feita utilizando-se de folhetos, cartazes, jogos, CDs / DVDs, páginas na internet, livros, instalações interativas, entre outros. Pode ser realizada ao ar livre, em museus, em escolas ou, mesmo, na própria residência do usuário, se utilizadas ferramentas que permitam a inclusão digital. 


\section{PROJETOS EM EXECUÇÃO NO BRASIL}

\subsection{Visão geral}

Um dos compromissos que necessita ser assumido pela comunidade geológica brasileira é o da união perante as ameaças sofridas pelo patrimônio geológico. Não são poucos os casos de denúncias e, mesmo, destruição de ambientes geológicos especiais como sítios paleontológicos e espeleológicos, dunas e outros ambientes costeiros, afloramentos únicos para a ciência e ensino.

Segundo Cendrero Uceda (1996) e Brilha (2005) a divulgação é uma importante ferramenta a ser utilizada em programas de geoconservação, cuja essência é a gestão científica para a conservação do patrimônio. A gestão, por sua vez, pressupõe a formalização de um gestor e de um programa baseado no conhecimento geológico e planejamento de ações de controle, divulgação e monitoramento. Este é um ponto crítico para a geoconservação no Brasil: as organizações de gestão ambiental, em geral, ainda não incorporam a proteção da geodiversidade na sua missão.

Por outro lado, a maioria das instituições estaduais de cunho geológico foi extinta entre os anos 1980 e 1990. Atualmente, apenas oito dos 26 estados brasileiros possuem instituições específicas voltadas para fomento da mineração e/ou conhecimento geológico. São eles: Bahia, Goiás, Mato Grosso, Paraíba, Paraná, Rio de Janeiro, São Paulo e Tocantins. Há, portanto, um descompasso entre o aumento do conhecimento geológico, com consequente geração de informação, e a capacidade de gestão do patrimônio identificado. Os dois mais antigos e prolíficos projetos de divulgação geológica do Brasil são gerenciados por serviços geológicos estaduais, DRM-RJ e MINEROPAR e, das oito instituições estaduais existentes, quatro delas, as de Goiás, Mato Grosso, Paraíba e Tocantins, ainda não iniciaram projeto de disseminação da geologia para a sociedade. Por outro lado, o Projeto Caminhos Geológicos da Bahia foi criado sem a coordenação da CBPM - Companhia Baiana de Pesquisa Mineral.

Em 2006, o Rio Grande do Norte, apesar de não possuir uma organização pública com foco específico na geologia e mineração, por meio do Instituto de Desenvolvimento Sustentável e Meio Ambiente, em convênio com a PETROBRAS, criou o Projeto Monumentos Geológicos do Rio Grande do Norte. Ainda, foi inaugurado um painel durante o Simpósio de Geologia do Sudeste, em 2007, pelo projeto Monumentos Geológicos de Minas Gerais (Figura 1), porém, não se tem notícias sobre perspectivas de sua continuidade.

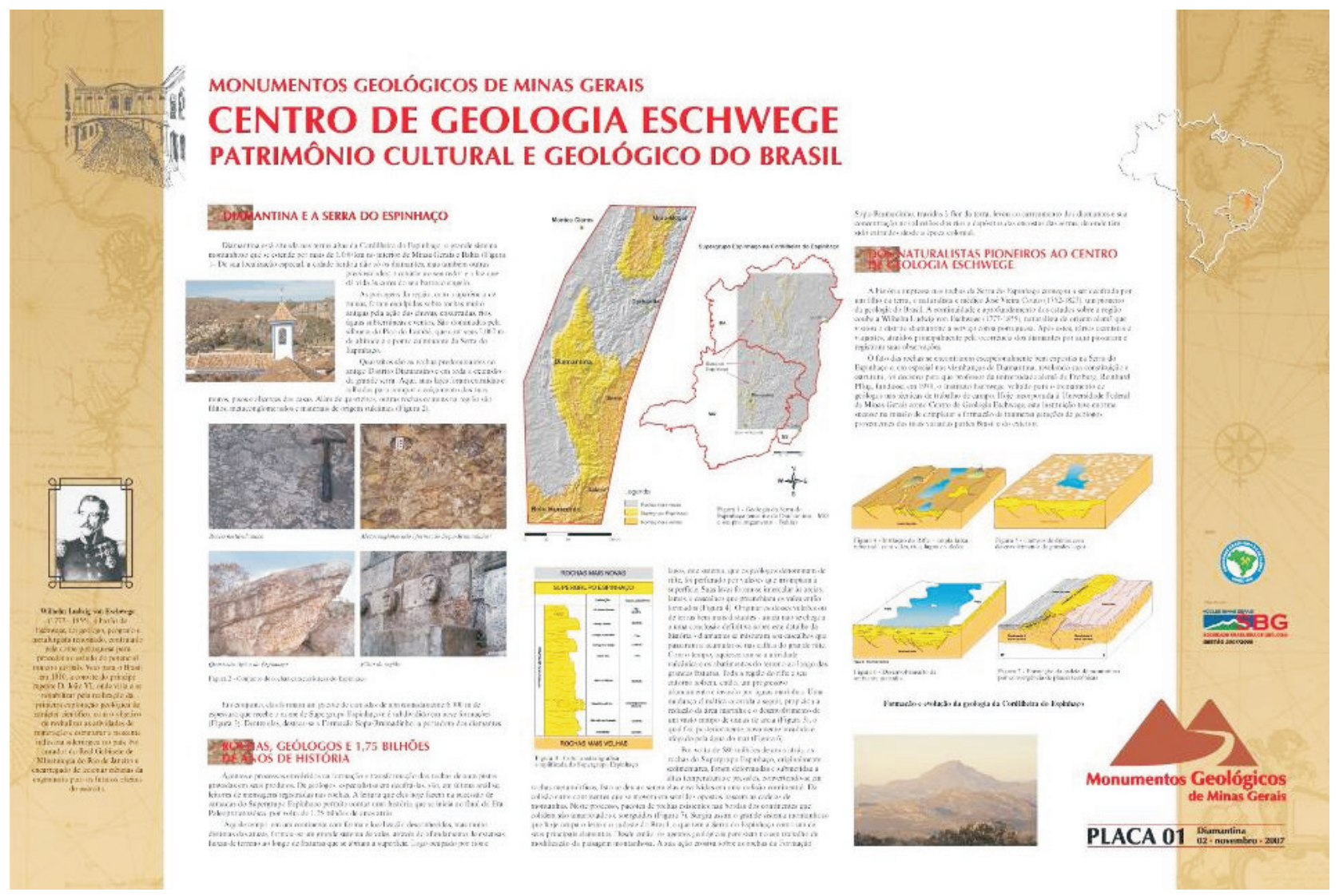

Figura 1-Painel inaugurado em 2007 no Centro de Geologia Eschwege, em Diamantina, MG 
Já em São Paulo, a instituição pública estadual de geologia, o Instituto Geológico - IG, está vinculado à Secretaria de Meio Ambiente - SMA e criou o Projeto Monumentos Geológicos. Esta vinculação tem permitido a aplicação de instrumentos clássicos da gestão ambiental à proteção do patrimônio geológico, como a criação do Conselho Estadual de Monumentos Geológicos, em 2009, para apoiar o IG na elaboração do inventário e na geoconservação. $\mathrm{O}$ conselho é consultivo e seus membros são representantes do poder público (SMA) e convidados com reconhecida atuação nos temas relacionados direta ou indiretamente com geossítios / monumentos geológicos.

\subsection{Ação da SIGEP}

A Comissão Brasileira de Sítios Geológicos e Paleobiológicos (SIGEP), criada em 1997, ocupou-se pela primeira vez no Brasil da identificação, avaliação, descrição e publicação de sítios do patrimônio geológico de forma sistêmica e com a participação essencial da comunidade geocientífica. Com suas atividades suspensas desde meados de 2012, por razões a seguir explicitadas, a SIGEP representou a mais importante e abrangente iniciativa no movimento pela conservação do patrimônio geológico nacional, seguida de algumas iniciativas em nível estadual.

Essa iniciativa descreveu e avaliou sítios geológicos e paleontológicos de valor excepcional - os chamados geossítios, feições notáveis identificadas no contexto da extensa diversidade geológica do país que representam a memória geológica nacional - patrimônio geológico do Brasil. Os geossítios são assim locais-chaves para o entendimento da história da dinâmica da Terra e da história da vida, desde a sua formação, razão pela qual precisam ser preservados. Muitos deles possuem extraordinária beleza paisagística.

O inventário do patrimônio geológico segue, sobretudo, critérios científicos, mas outros tipos de interesses são considerados, a exemplo do interesse educativo que é essencial para a formação de alunos e professores de todos os níveis de ensino ao serem colocados frente a frente com a realidade da geologia, representada no geossítio por rochas, minerais e feições geológicas, um verdadeiro arquivo da natureza. Por outro lado, o interesse turístico e cultural é importante na promoção da geologia junto ao público leigo e pode contribuir para o desenvolvimento sustentado das populações locais.

A Comissão Brasileira dos Sítios Geológicos e Paleobiológicos - SIGEP, contou com representantes das seguintes instituições: Academia Brasileira de Ciências $A B C$, Associação Brasileira para Estudos do Quaternário ABEQUA, Departamento Nacional de Produção Mineral DNPM, Instituto Brasileiro de Geografia e Estatística IBGE, Instituto Brasileiro do Meio Ambiente e dos Recursos Naturais Renováveis - IBAMA, Instituto Chico
Mendes de Conservação da Biodiversidade - ICMBio, Instituto do Patrimônio Histórico e Artístico Nacional IPHAN, Petróleo Brasileiro S/A - PETROBRAS, Serviço Geológico do Brasil - CPRM, Sociedade Brasileira de Espeleologia - SBE, Sociedade Brasileira de Geologia SBG, Sociedade Brasileira de Paleontologia - SBP e União da Geomorfologia Brasileira - UGB.

A principal atribuição da SIGEP - de elencar os geossítios brasileiros - foi implementada com o gerenciamento de um banco de dados nacional e disponibilizado em site da internet (http://sigep.cprm.gov.br) na forma de artigos científicos bilíngues - inglês e português - elaborados por especialistas que trabalharam nas áreas dos geossítios aprovados.

Desde o início, o processo seletivo dos geossítios seguiu a orientação da SIGEP de avaliação de cada sítio segundo sua tipologia principal (Astroblema; Espeleológico; Estratigráfico; Geomorfológico; Hidrogeológico - só casos especiais; História da Geologia, Mineração, Paleontologia; Ígneo; Marinho-submarino; Metamórfico; Metalogenético; Mineralógico; Paleoambiental; Paleontológico; Sedimentar; Tectonoestrutural; outro) e tendo como critérios: (i) sua singularidade na representação de sua tipologia ou categoria; (ii) importância na caracterização de processos geológicos-chave regionais ou globais, períodos geológicos e registros expressivos na história evolutiva da Terra; (iii) expressão cênica; (iv) bom estado de conservação; (v) acesso viável; e (vi) existência de mecanismos ou possibilidade de criação de mecanismos que the assegure conservação e consequente aproveitamento.

Mesmo instituída e exercendo de fato as suas competências, a SIGEP não foi oficializada de direito no âmbito do Poder Público, o que lhe tirava a capacidade de adotar medidas legais para a preservação dos geossítios. Assim, em agosto de 2012, quinze anos depois de sua criação, a SIGEP, suspendeu o recebimento de novas propostas de geossítios em virtude da publicação de Portaria N0 170, de 20 de junho de 2012, da Secretaria de Geologia, Mineração e Transformação Mineral do Ministério de Minas e Energia que instituiu o Grupo de Trabalho Interministerial de Sítios Geológicos e Paleontológicos (GTI-SIGEP) com a responsabilidade de propor a institucionalização das atividades da SIGEP e a revisão dos procedimentos afetos à seleção de novos sítios geológicos e paleontológicos de natureza especial e ao gerenciamento e divulgação de tais informações, ou seja, com o objetivo de instituir o marco legal que permitirá impulsionar, de forma oficial, a identificação, a preservação, divulgação, valorização e uso de sítios representativos do patrimônio geológico e paleontológico brasileiro.

O GTI-SIGEP concluiu suas atividades em novembro de 2012 ao apresentar minuta de proposta de edição de decreto presidencial, objetivando a criação da 
Comissão do Patrimônio Geológico do Brasil, com as atribuições de identificar e reconhecer os bens que constituem o Patrimônio Geológico do Brasil e definir e encaminhar propostas de acautelamentos aos órgãos competentes.

Sintetizando, pode-se dizer que a SIGEP, uma comissão multi-institucional, coordenou e promoveu entre 1997 e 2012, de mãos dadas com a comunidade geocientífica, o inventário parcial de sítios geológicos e paleontológicos do Brasil a serem preservados na forma de artigos científicos complementados por sugestões de medidas de proteção.

A ampla divulgação na internet e em volumes impressos (livros) (Figura 2), atingindo não só os órgãos públicos - municipais, estaduais e federal, mas também o setor privado e a opinião pública em geral, certamente é da maior importância para propiciar a preservação e bom uso do patrimônio natural, através da necessária sinergia entre os vários órgãos públicos, empresas interessadas e comunidade, envolvidos na preservação da geodiversidade.

Números referentes à produção da SIGEP registrados no site ou publicados (Schobbenhaus et al. 2002, Winge et al. 2009, Winge et al. no prelo) são apresentados a seguir:

- 116 geossítios publicados em 3 volumes e disponibilizados em PDF na internet (Figura 3);

- 51 geossítios aprovados, mas sem descrição disponível (Figura 4);

- 4 geossítios dos publicados em versão para leigos publicados na internet;

- 26 sugestões preliminares de geossítios não formalizadas;

- 26 propostas de geossítios canceladas (causas: pouca relevância, superposição com outras propostas, destruição).
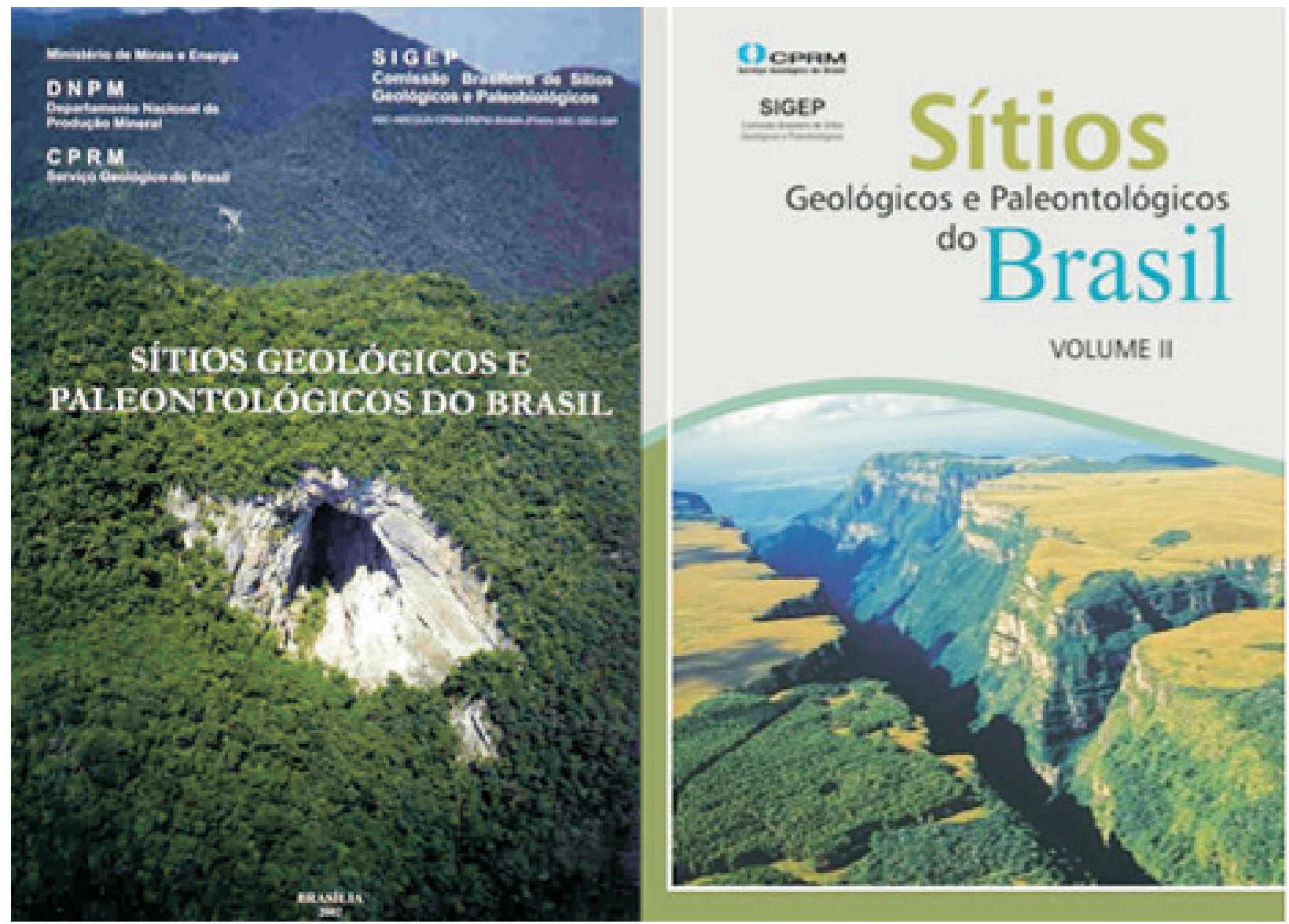

Figura 2-Capas dos volumes I e II da SIGEP. Acessíveis em: http://sigep.cprm.gov.br 


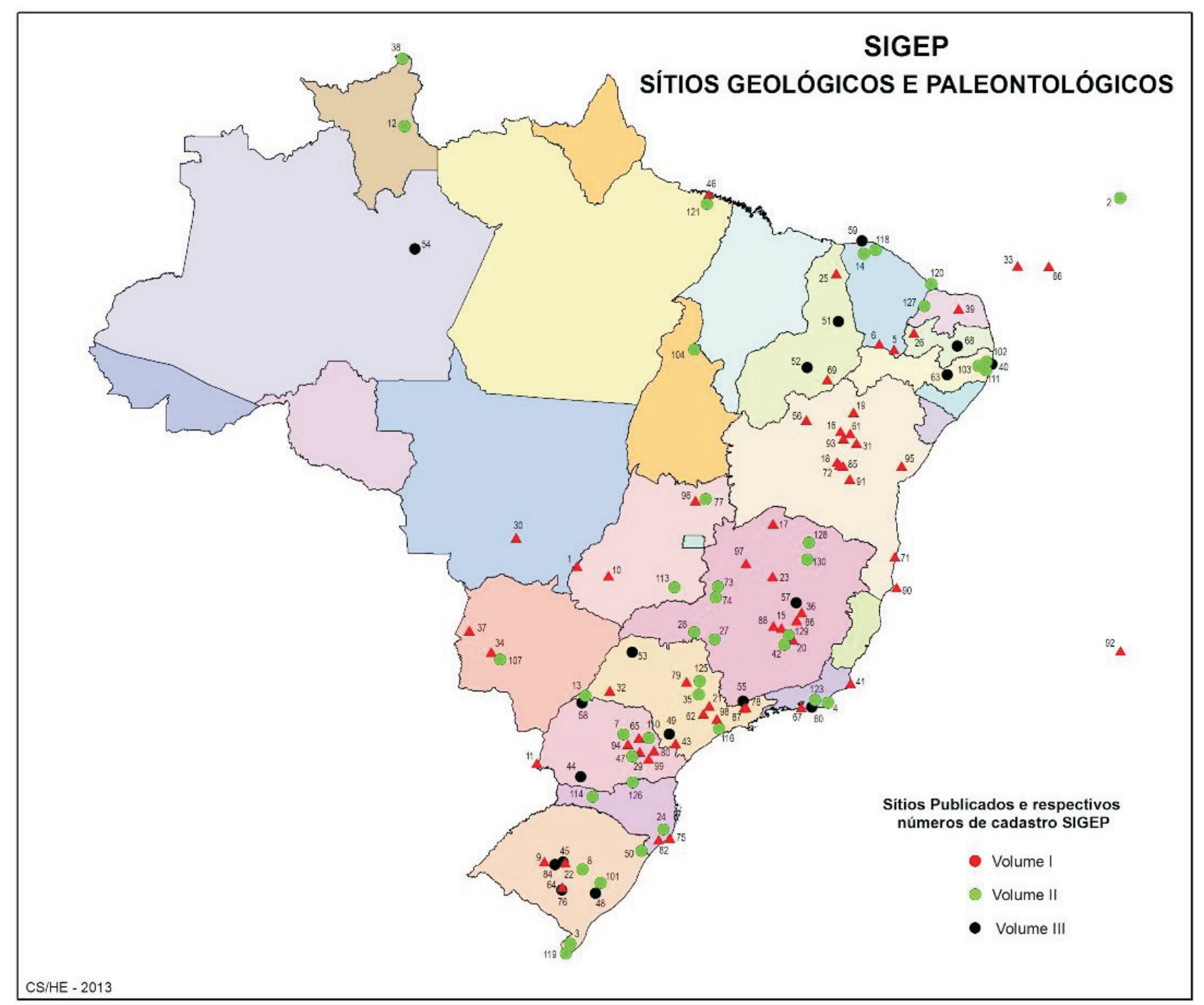

Figura 3 - Localização dos sítios aprovados pela Comissão Brasileira de Sítios Geológicos e Paleobiológicos - SIGEP, publicados na forma de artigos científicos e complementados por sugestões de medidas de proteção. 


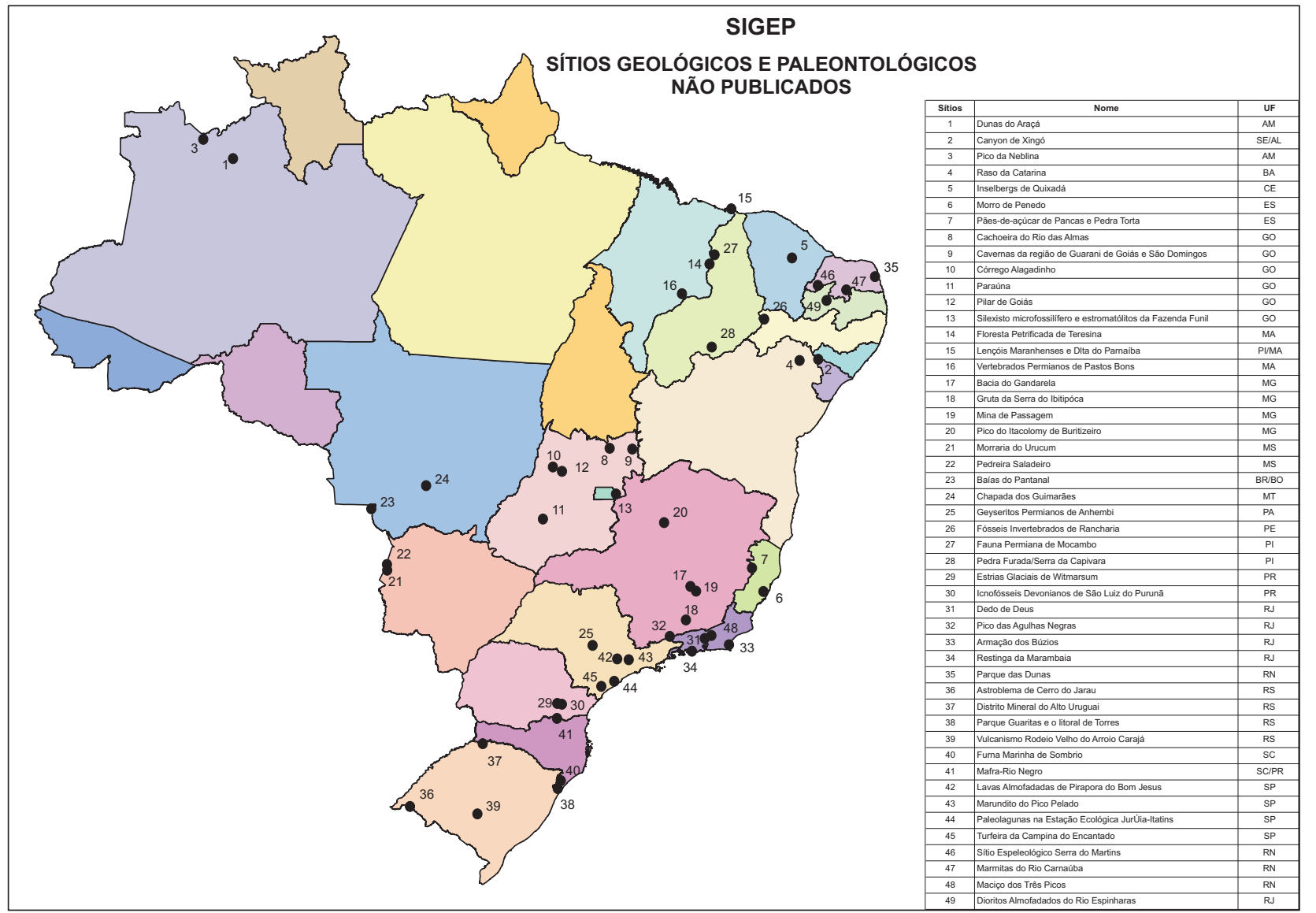

Figura 4 - Localização dos sítios aprovados pela Comissão Brasileira de Sítios Geológicos e Paleobiológicos - SIGEP, sem número de cadastro SIGEP e sem publicação disponível na forma de artigo científico.

\subsection{Projetos do Serviço Geológico do Brasil - CPRM}

\subsubsection{Geoparques}

A CPRM tem como uma de suas missões precípuas a geração e a difusão de informações geológicas. Por ser o grande gerador e detentor do conhecimento geológico nacional, cabe ao Serviço Geológico do Brasil com o apoio da área acadêmica e dos serviços geológicos estaduais, realizar de forma sistemática o inventário dos sítios do patrimônio geológico do Brasil, tanto de importância internacional, quanto nacional ou regional/local.

A CPRM promove a identificação, caracterização e avaliação, visando à conservação do patrimônio geológico brasileiro através do Projeto Geoparques. Os sítios geológicos ou geossítios cadastrados e quantificados pelo Projeto Geoparques são destinados a integrar um acervo para a preservação do patrimônio geológico. Também, como membro da SIGEP, a CPRM se ocupou nos últimos 15 anos da identificação, avaliação, descrição e publicação de geossítios.

Um geoparque corresponde a uma área com limites bem definidos e com uma dimensão suficiente para que possa servir ao desenvolvimento econômico e cultural local (especialmente por meio do geoturismo) (http://www.unesco.org/new/en/naturalsciences/environment/earth-sciences/geoparks/globalgeoparks-network/). Os sítios devem ser importantes do ponto de vista da ciência, raridade, educação e / ou estética. Um geoparque é uma área onde geossítios fazem parte de um conceito holístico de proteção, educação e desenvolvimento sustentável. No entanto, o geoparque deve levar em conta o contexto da região e não unicamente incluir locais de significado geológico. A sinergia entre a biodiversidade, geodiversidade e cultura, além do patrimônio tangível e não tangível devem ser de tal ordem que temas não geológicos devem ser destacados como parte integrante do geoparque, especialmente quando a sua importância em relação à paisagem e geologia pode ser demonstrado aos visitantes. Por essa razão, é necessário também incluir e destacar locais de interesse ecológico, arqueológico, histórico e cultural dentro do geoparque (UNESCO 2010).

O programa Geoparque vem suprir uma lacuna para reconhecimento internacional do patrimônio geológico de importância nacional ou regional. A iniciativa da UNESCO para apoiar os geoparques, bem sucedida em nível mundial, responde à forte demanda expressa por muitos países, que tem como objetivo, entre outros, constituir uma série global de sítios geológicos ou geossítios destinados a integrar um acervo para a preservação do patrimônio geológico. 
Nesse sentido, os geossítios são vistos como complementares à Lista do Patrimônio Mundial da UNESCO, possibilitando desenvolver um mecanismo adequado para o reconhecimento de locais de importância internacional, identificados a partir de inventários geológicos nacionais (UNESCO 2008; Eder \& Patzak 2004).

O Projeto Geoparques da CPRM representa importante papel indutor na proposição de geoparques no território nacional. Esse projeto tem como premissa básica a identificação, levantamento, descrição, diagnóstico e ampla divulgação de áreas com potencial para futuros geoparques no território nacional. Durante esse processo realiza-se o cadastro e quantificação de geossítios de diversas tipologias, dentro dos limites do proposto geoparque. Para esse trabalho concorre o acervo de levantamentos geológicos existentes no País e a experiência do corpo técnico da empresa, além do aporte de estudos e propostas da comunidade geocientífica. Em alguns casos, essa atividade indutora é feita em conjunção com universidades e outros órgãos ou entidades federais, estaduais ou municipais que tenham interesses comuns, em consonância com as comunidades locais. A ação catalisadora desenvolvida pela CPRM representa, entretanto, somente o passo inicial do futuro geoparque. As áreas propostas para os geoparques foram selecionadas por sua importância geológica, que em muitos casos associa-se a formas de relevo com excepcional valor estético ou beleza cênica. Nessa etapa inicial as áreas propostas pelo Projeto Geoparques constituem em primeira instância parques geológicos, que possibilitam conhecer a sua história geológica através dos geossítios, roteiros geológicos ou pela geomorfologia da paisagem.

Para a transformação de um parque geológico em um geoparque, além dos atributos geológicos, outros atributos devem coexistir na área proposta e ambos deverão promover o desenvolvimento econômico sustentável e a geoconservação, comumente através do geoturismo/ecoturismo. Em praticamente todas as áreas selecionadas para os geoparques potenciais, já existe um fluxo turístico, em maior ou menor grau, no entanto, sem associação direta com a geologia. A criação de uma entidade de gestão e outras iniciativas complementares permitirá que o parque geológico seja transformado em um geoparque, cabendo-Ihe promover o geoturismo. Alguns geoparques propostos coincidem em seus limites com unidades de conservação ou parques naturais, em especial por apresentarem rara beleza cênica. No entanto, os limites de um geoparque não coincidem necessariamente com os parques naturais ou outras áreas de reservas ambientais. Propostas de áreas com potencial de se transformarem em geoparques, objeto do Projeto Geoparques, estão indicadas na Figura 5.

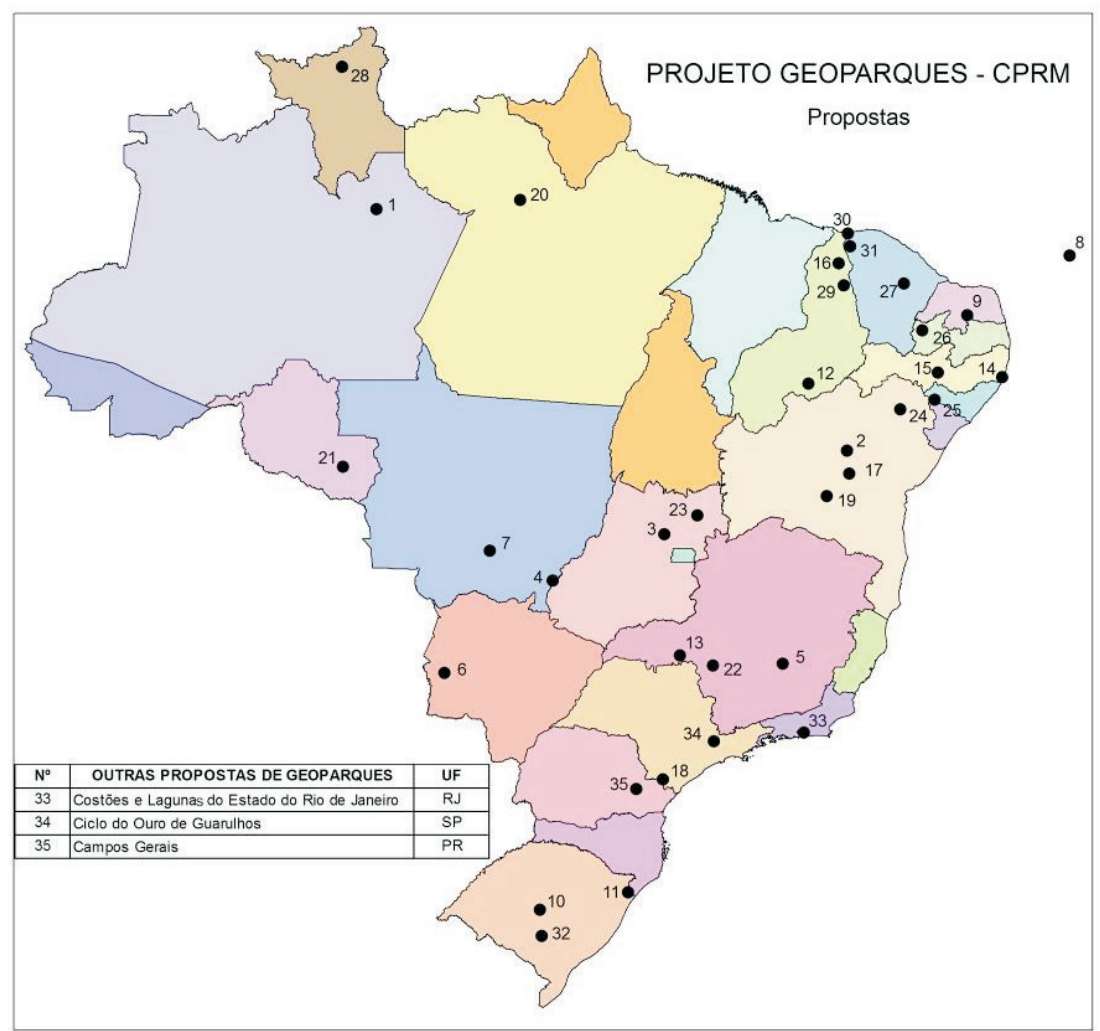

\begin{tabular}{|c|c|c|}
\hline $\mathbf{N}^{\circ}$ & GEOPARQUES & UF \\
\hline 1 & Cachoeiras do Amazonas & AM \\
\hline 2 & Morro do Chapéu & BA \\
\hline 3 & Pireneus & GO \\
\hline 4 & Astroblema de Araguainha-Ponte Branca & GO/MT \\
\hline 5 & Quadrilátero Ferrifero & MG \\
\hline 6 & Bodoquena-Pantanal & MS \\
\hline 7 & Chapada dos Guimarães & MT \\
\hline 8 & Fernando de Noronha & PE \\
\hline 9 & Seridó & RN \\
\hline 10 & Quarta Colônia & RS \\
\hline 11 & Caminhos dos Cânions do Sul & $\mathrm{RS} / \mathrm{SC}$ \\
\hline 12 & Serra da Capivara & $\mathrm{PI}$ \\
\hline 13 & Uberaba, Terra dos Dinossauros & MG \\
\hline 14 & Litoral Sul de Pernambuco & PE \\
\hline 15 & Catimbau-Pedra Furada & $\mathrm{PE}$ \\
\hline 16 & Sete Cidades-Pedro II & $\mathrm{PI}$ \\
\hline 17 & Chapada Diamantina & $\mathrm{BA}$ \\
\hline 18 & Alto Vale do Ribeira & SP \\
\hline 19 & Rio de Contas & BA \\
\hline 20 & Monte Alegre & PA \\
\hline 21 & Alto Alegre dos Parecis & RO \\
\hline 22 & Serra da Canastra & MG \\
\hline 23 & Chapada dos Veadeiros & GO \\
\hline 24 & Canudos & $\mathrm{BA}$ \\
\hline 25 & Cânion do São Francisco & SE/AL \\
\hline 26 & Rio do Peixe & PB \\
\hline 27 & Vale Monumental & CE \\
\hline 28 & Tepuis & RR \\
\hline 29 & Cânion do Rio Potí & $\mathrm{PI}$ \\
\hline 30 & Delta do Parnaiba & $\mathrm{PI}$ \\
\hline 31 & Ubajara & $\mathrm{CE}$ \\
\hline 32 & Guaritas-Minas do Camaquã & RS \\
\hline
\end{tabular}

Figura 5 - Mapa de localização das propostas de geoparques concluídas (1 a 17), em execução e programadas do Projeto Geoparques da CPRM. 
Nos últimos cinco anos foram concluídos estudos de 17 propostas de geoparques pelo Projeto Geoparques cobrindo áreas de norte a sul do país. Dessas, 14 foram publicadas pela CPRM no primeiro volume do livro "Geoparques do Brasil-Propostas" (Schobbenhaus \& Silva 2012). Diversas outras propostas estão em fase de avaliação ou serão avaliadas em etapas seguintes.

Uma atividade essencial realizada pelo Projeto Geoparques é a identificação, cadastramento e valoração de geossítios ou sítios do patrimônio geológico na área do território proposto para o potencial geoparque. Até o momento foram cadastrados 376 geossítios nos 17 propostos geoparques. Esses geossítios apresentam diferentes pontos de interesse: científico, didático, turístico, cultural e outros. A sua importância varia de regional/local (59\%), nacional (31\%) a internacional (10 $\%)$. Dentro das áreas propostas para geoparques, cerca de $48 \%$ relacionam-se a geossítios do Pré-Cambriano, 24\% do Paleozoico, 24\% do Mesozoico e o restante do Cenozoico. Os litótipos mais comuns são de interesse geomorfológico, estratigráfico e paleoambiental, normalmente associados a geoformas de valor estético ou beleza cênica. Outros são paleontológicos, ígneos, petrológicos, metalogenéticos e espeleológicos. Outros ainda incluem importantes registros da história da mineração ou ainda tem importantes valores préhistóricos e histórico-culturais associados.

\subsubsection{Geossit}

As atividades do Projeto Geoparques abrangem o cadastramento e a quantificação de geossítios, contemplando as metodologias de Brilha (2005) e GarciaCortés \& Urquí (2009), adaptadas ao Brasil. Independentemente das futuras ações a serem tomadas com relação aos propostos geoparques, o cadastramento dos geossítios realizado será incorporado em uma atividade mais ampla de âmbito nacional: o Inventário de Sítios do Patrimônio Geológico do Brasil. Para permitir a alimentação de um banco de dados a CPRM desenvolveu um aplicativo web para cadastramento e quantificação automática de geossítios, denominado GEOSSIT (Lima et al. 2012). O aplicativo GEOSSIT é uma ferramenta para a padronização do cadastramento de geossítios do Brasil. É de livre consulta e será operado por meio de uma base de dados específica do Sistema GEOBANK do Serviço Geológico do Brasil - CPRM. O aplicativo web GEOSSIT é operado mediante utilização das seguintes ferramentas de software livre: linguagem de programação PHP 5.3 e banco de dados MySQL 5.1.

As informações solicitadas (localização, caracterização geológica e geomorfológica, áreas de interesse, presença de unidades de conservação, etc.), seguidas da quantificação das características intrínsecas, do uso potencial e da necessidade de proteção, permitem classificar o geossítio como de interesse regional, nacional ou internacional (metodologia de Brilha 2005) e definir o valor relativo quanto ao interesse científico, didático e turístico (metodologia de GarciaCortés \& Carcavilla 2009).

A metodologia de Garcia-Cortés \& Urquí (2009) permite também o cálculo da vulnerabilidade do geossítio cujo valor adicionado ao valor do interesse cientifico, didático ou turístico, permite estabelecer a urgência para que sejam adotadas medidas de proteção ao geossítio.

Apesar de originalmente o GEOSSIT estar vinculado ao Projeto Geoparque, gradativamente foi ficando claro o potencial de sua utilização como ferramenta para alimentar um banco de dados nacional de geossítios. Desse modo, o GEOSSIT será integrado ao banco de dados da CPRM, denominado GEOBANK. Para acessar o a plicativo o endereço é www.cprm.gov.br/geossit, sendo que a visualização dos dados preenchidos pode ser efetuada clicando no nome do geossítio. O aplicativo possui o módulo de preenchimento (exige senha) e o módulo de visualização (acesso livre).

\subsubsection{Sinalização Interpretativa no Quadrilátero Ferrífero}

Projeto financiado pelo Serviço Geológico do Brasil (CPRM) em parceria com a Universidade Federal de Minas Gerais e executado pelo Instituto Terra Brasilis, no contexto da proposta do Geoparque Quadrilátero Ferrífero. Em sua primeira etapa, o projeto teve como principal objetivo a elaboração, confecção e instalação de placas com informações geológicas em sítios do Quadrilátero Ferrífero, com linguagem acessível e bilíngue (português e inglês), aproximando o cidadão comum de seu patrimônio geológico e promovendo a geoconservação. Os sítios contemplados foram: Serra do Rola Moça, Serra da Piedade, Serra do Curral, Gnaisse de Cachoeira do Campo e Pico do Itacolomi. Os painéis de sinalização do Geopark Quadrilátero Ferrífero foram idealizados em modelo único no formato prancheta com ângulo de inclinação confortável à leitura. Levou-se em conta para isto as características dos locais sinalizados, em sua maioria, áreas de mirante, onde a disposição no formato prancheta favorece a apreciação da paisagem (Figura 6).

Cada painel é composto por dois módulos, no módulo da esquerda são apresentadas as informações sobre o conceito de Geoparque e sobre a geologia do Quadrilátero Ferrífero. Já no módulo da direita são apresentadas as informações sobre o geossítio propriamente dito, focando suas peculiaridades e atrativos, contextualizando-o na proposta do Geoparque (Ruchkys et al. 2012). 

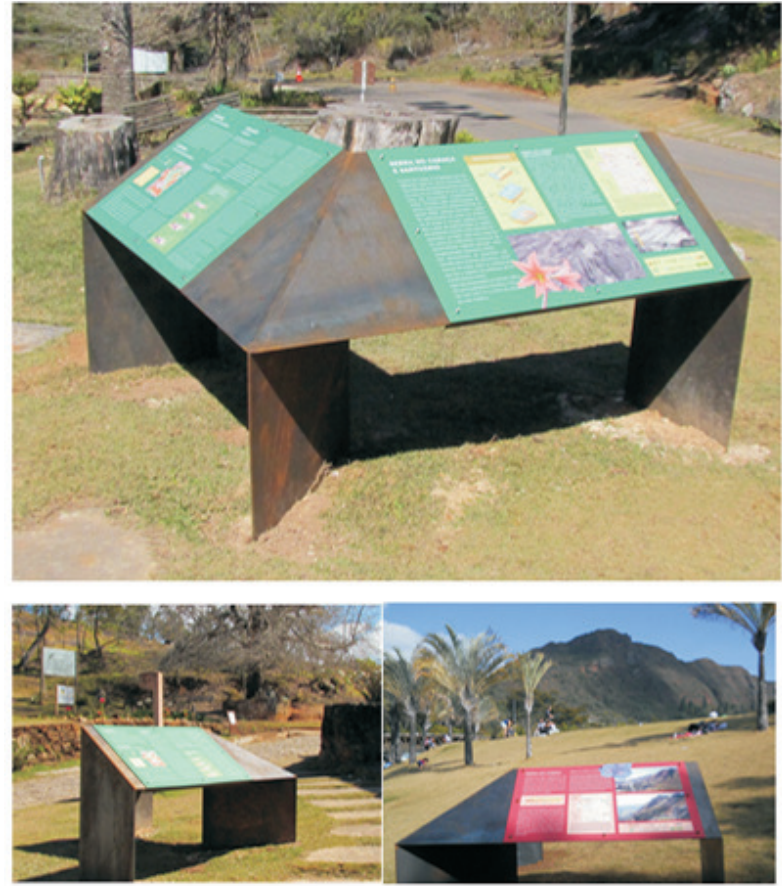

Figura 6 - Exemplos de painéis de sinalização interpretativa na Serra do Caraça e Parque das Mangabeiras, Quadrilátero Ferrífero, MG. Fotos: Andreá Trevisol.

\subsection{Caminhos Geológicos do Estado do Rio de Janeiro}

O projeto Caminhos Geológicos foi concebido em 2000 e inaugurado em 2001, pelo DRM-RJ - Serviço Geológico do Estado do Rio de Janeiro. Seu objetivo geral é popularizar a geologia pela implantação de painéis interpretativos nos principais monumentos geológicos do Estado do Rio de Janeiro. Como decorrência, se transformou num projeto que tem um forte apelo na geoconservação. São objetivos específicos: (a) Reconhecer e preservar os monumentos geológicos do Estado do Rio de Janeiro; (b) Divulgar o conhecimento geológico entre as comunidades e também para profissionais e cidadãos em geral; (c) Incentivar o desenvolvimento socioeconômico relacionado com a geologia; e (d) Fortalecer o potencial turístico das regiões, criando novos circuitos de visitação a partir de uma proposta ecológica, científica e cultural.

É um projeto que conta com a parceria fixa do Departamento de Estradas de Rodagem - DER-RJ e da Cia de Turismo do Estado - Turisrio. Tem nas universidades que estudam a geologia fluminense a base da parceria científica que confere credibilidade ao projeto. Recebe apoio de prefeituras, ONGs, empresas públicas e privadas e de agências de fomento, como a FAPERJ.

Como foi o primeiro projeto de sinalização sistemática do Brasil, vem cumprindo um papel de indutor de experiências semelhantes em outros estados. Da mesma forma, teve participação decisiva na formatação do Simpósio sobre Monumentos Geológicos, no XLII Congresso Brasileiro de Geologia, em Araxá, em 2004, primeira experiência com esta temática no mais importante evento brasileiro de geologia que, atualmente, já possui réplicas em muitos dos eventos regionais e temáticos.

A comunicação com os não geólogos através da linguagem, escrita ou visual, sempre foi o grande desafio do projeto e, por este motivo, ele vem sendo construído a partir da interação com as comunidades onde os painéis são implantados. A metodologia básica de elaboração e localização dos painéis do Projeto Caminhos Geológicos do Estado do Rio de Janeiro foi publicada por Mansur \& Nascimento (2007).

Até abril de 2013 foram implantados 104 painéis em 31 municípios, cuja manutenção é um item importantíssimo a ser considerado (Figuras 7 e 8).

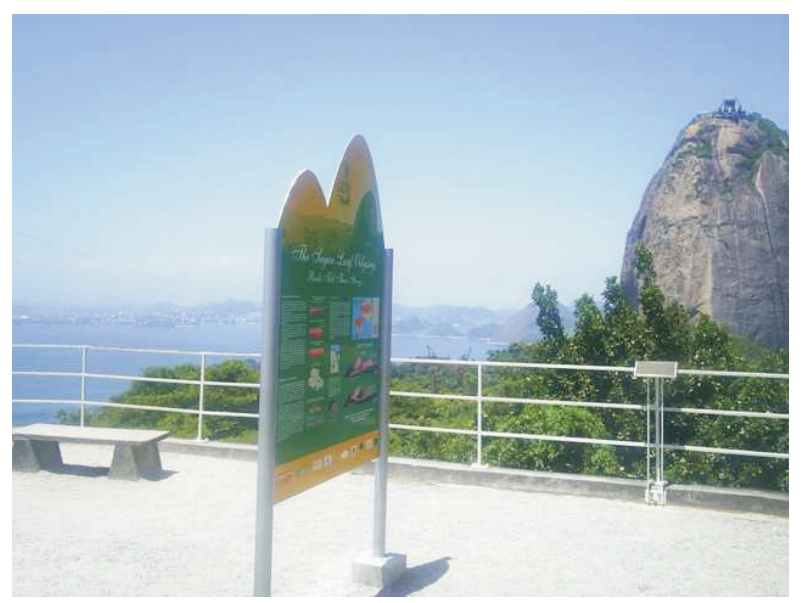

Figura 7 - Painel interpretativo implantado no Pão de Açúcar

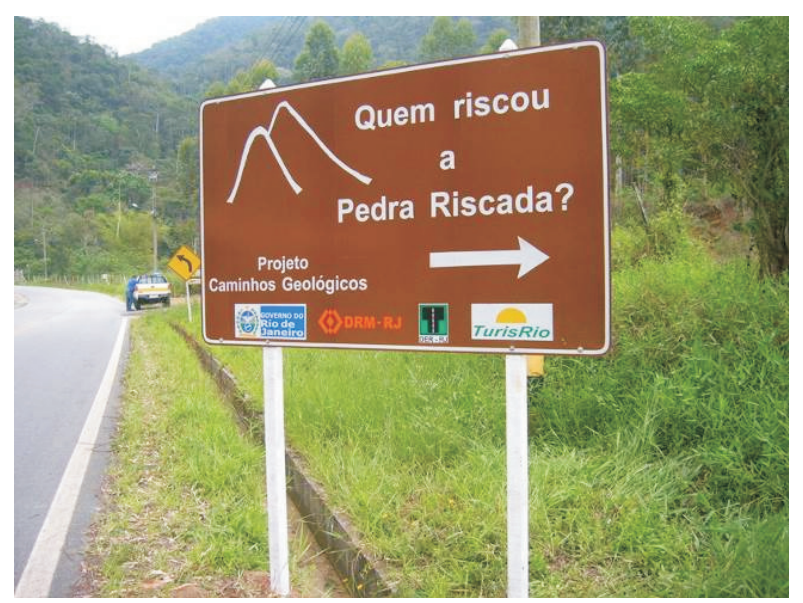

Figura 8-Placa de estrada, indicativa de painel interpretativo.

Seu desenvolvimento envolve ações que avançam além da colocação dos painéis interpretativos, consolidando-se na vertente educacional (Mansur 2009a) e outras. Assim, são realizadas ações:

a) na comunidade escolar, envolvendo alunos e professores, trabalhos de campo e elaboração de material didático e paradidático próprio (Talarico 2004; Talarico et al. 2005, Mansur 2009a) (Figuras 9 e 10); 


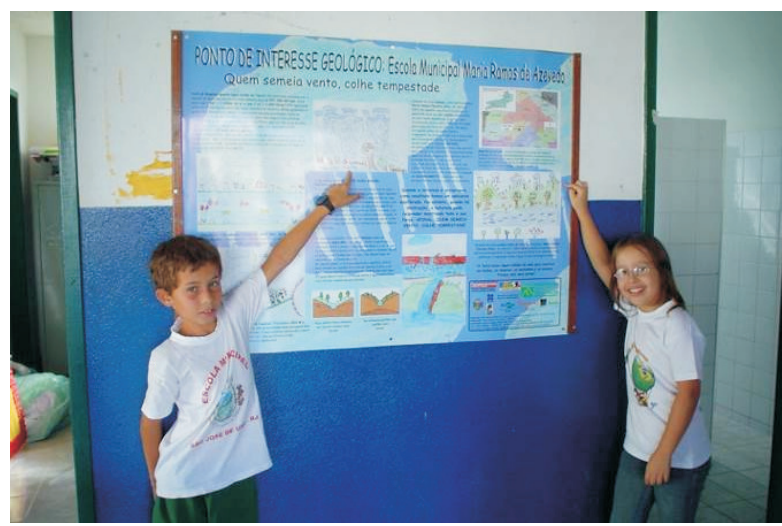

Figura 9-Alunos de São José de Ubá, apontando seus desenhos no painel colocado em sua escola.

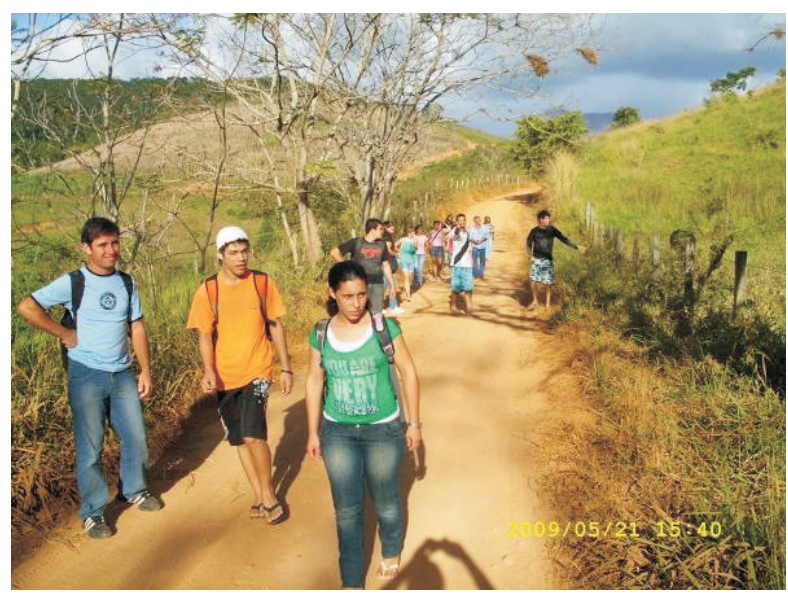

Figura 10 - Alunos do Projeto Jovens Talentos para a Ciência em trabalho de campo em Santo Antônio de Pádua

b) junto à sociedade civil organizada como ONGs, associações de moradores, comitês de bacia, conselhos gestores de Unidades de Conservação - UCs (Nascimento \& Mansur 2008), gestores ambientais e coletivos educadores ambientais, como os livros do Projeto Conhecer para Preservar (Mansur et al. 2007a, 2007b) (Figuras 11 e 12);

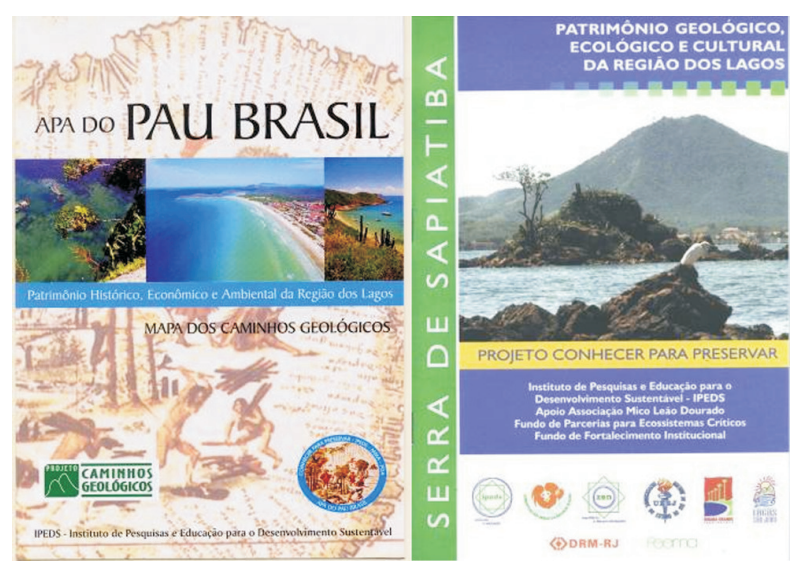

Figura 11 - Publicações sobre geologia de UCs, organizadas pelo Coletivo Educador Conhecer para Preservar.

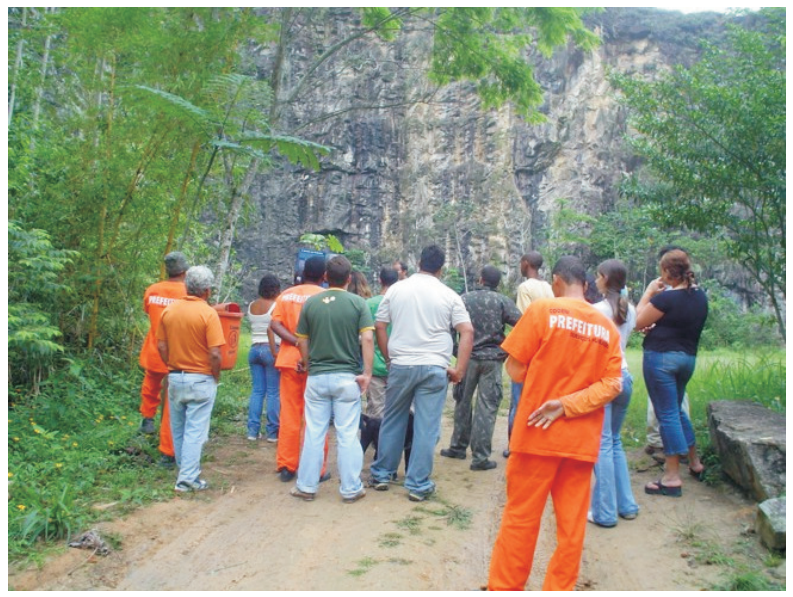

Figura 12 - Treinamento sobre geologia para os funcionários do Parque Natural Municipal de Nova Iguaçu

c) na governança local, incluindo prefeituras, produtores rurais (Figura 13), APLs de base turística;

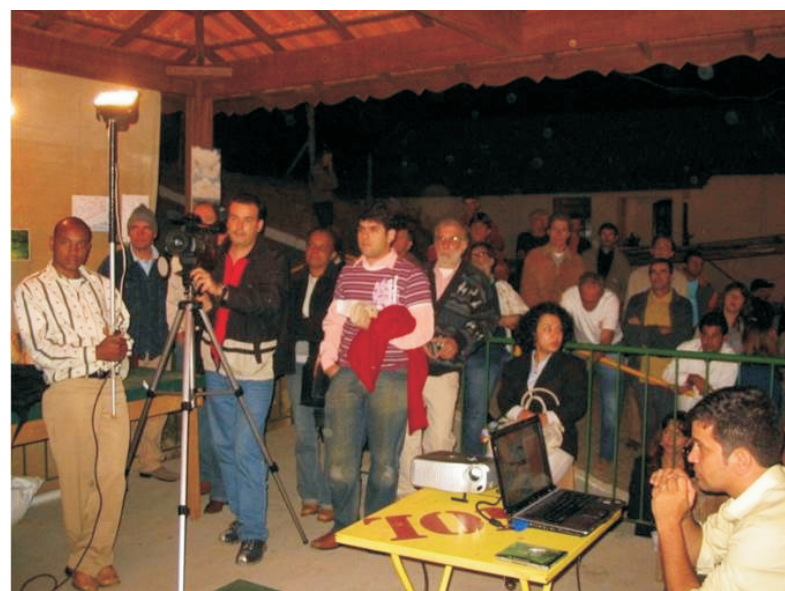

Figura 13 - Apresentação sobre geologia em praça pública para produtores rurais em Bom Jardim

d) no meio acadêmico, apoiando e realizando conjuntamente pesquisas geológicas com Universidades, como UFF (Figueiredo Jr et al. 2004), UERJ (Schmitt et al. 2004, Valeriano 2006); UENF (Alves et al. 2009) e UFRJ e Museu Nacional (Mansur et al. 2009b) ou na orientação acadêmica de alunos;

e) na parceria com museus, como o Museu da Geodiversidade da UFRJ (Carvalho et al. 2009), e outras entidades que trabalham na popularização da ciência, como a Casa da Ciência da UFRJ e o MCTI - Departamento de Divulgação e Popularização da Ciência, por meio do Projeto Caminhos de Darwin (Moreira et al. 2009, Mansur 2009d) (Figura 14); 


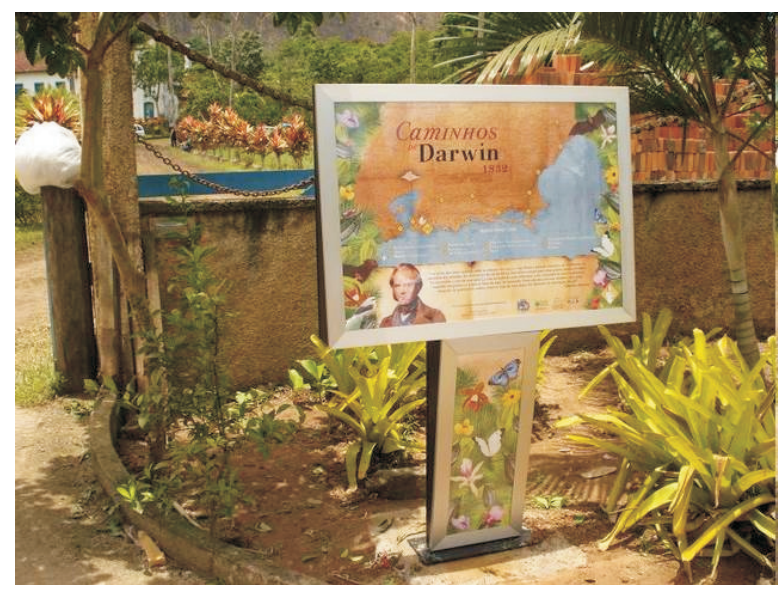

Figura 14-Painel do Projeto Caminhos de Darwin em Maricá

f) na esfera patrimonial, atuando com o INEPAC (Schmitt et al. 2004) e IPHAN (Mansur et al. 2008), além das entidades municipais, no tombamento e preservação de bens de natureza geológica (Mansur et al. 2009b).

Também, na expectativa de ampliar o horizonte de usuários (ou "visitantes") do projeto, foi elaborada $\mathrm{u} \mathrm{m}$ a pág i n a d a i n t e r n e t (www.caminhosgeologicos.rj.gov.br) que apresenta informações teóricas e abordagens didáticopedagógicas, como jogos, quebra-cabeças e textos voltados para o público jovem. Possui um webmapa onde se pode acessar cada painel na íntegra, com fotos dos monumentos e possibilidade de envio de cartões-postais personalizados. Garcia et al. (2008) apresentam a ficha técnica do desenvolvimento da página, quase exclusivamente baseada em softwares livres. Porém, um dos mais importantes itens da página, que ainda está em alimentação, é o inventário dos monumentos geológicos do Estado do Rio de Janeiro, associado a um esquema de valoração dos bens (Mansur \& Carvalho 2010).

Em pesquisa de opinião realizada em locais onde estão localizados painéis do Projeto Caminhos Geológicos, em 2008, 89\% dos entrevistados acreditam que eles são eficientes para a preservação dos patrimônios geológicos sinalizados (Mansur \& Silva 2011).

\subsection{Programa Sítios Geológicos e Paleontológicos do Estado do Paraná}

O programa Sítios Geológicos e Paleontológicos do Paraná da Mineropar vem ao encontro do movimento global sobre o inventário, conservação, valorização, divulgação e uso sustentável do patrimônio geológico no âmbito do Estado do Paraná. Levando-se em consideração que o patrimônio geológico é um patrimônio natural, as ações já desenvolvidas no programa, inserido em atuações de diversos órgãos governamentais e não governamentais, tiveram como escopo o cumprimento das seguintes metas:

a) definir a política de administração do patrimônio geológico do Paraná, inserindo estas políticas nas comunidades locais, inclusive para sua conservação;

b) inventariar e selecionar os principais sítios geológicos do Estado do Paraná, com o intuito de democratizar a informação e o conhecimento científico;

c) integrar estas informações a programas de turismo ou geoturismo;

d) formar e treinar guias e/ou condutores nas comunidades próximas aos sítios geológicos selecionados visando à geração de emprego e renda, bem como à sustentabilidade física e financeira dos sítios com o envolvimento da comunidade.

Os trabalhos necessários para o desenvolvimento do projeto envolveram a confecção de um inventário inicial, onde foram cadastrados os sítios geológicos e paleontológicos de valor turístico mais relevante do estado. Posteriormente foram escolhidos alguns sítios, de notória relevância, como locais pilotos para a implantação de painéis e confecção de folhetos. $O$ método está centrado em criar aparatos e materiais que estimulem o aprendizado a respeito do ambiente natural e sua formação e/ou evolução ao longo do tempo geológico.

\subsubsection{Inventário}

O inventário do patrimônio geológico do Paraná foi realizado tendo por base dois enfoques principais: o primeiro apoia-se na identificação da demanda do geoturismo, contemplando-se as principais atrações paisagens, afloramentos, pontos geológicos, geomorfológicos e paleontológicos notáveis em unidades de conservação, municípios, paisagens com abrangência restrita e/ou em simples afloramentos, todos com significativa visitação e, portanto, com demandas por explicação geológica mais acurada. 0 segundo caminho, em contínuo desenvolvimento e aprimoramento, segue a confecção e o preenchimento de um banco de dados (Figura 15) com informações das características geológicas, geomorfológicas e paleontológicas, com informações acerca da identificação e da localização, além de informações sobre outras observações a respeito dos sítios selecionados.

Esse banco de dados serve para a quantificação e a classificação dos geossítios paranaenses. Sua elaboração embasou o desenvolvimento de projetos de roteiros geoturísticos, especificamente os roteiros denominados de "Geoturismo na Rota dos Tropeiros", "Geoturismo em Curitiba" e "Geoturismo no Karst", os dois últimos na região metropolitana de Curitiba. 


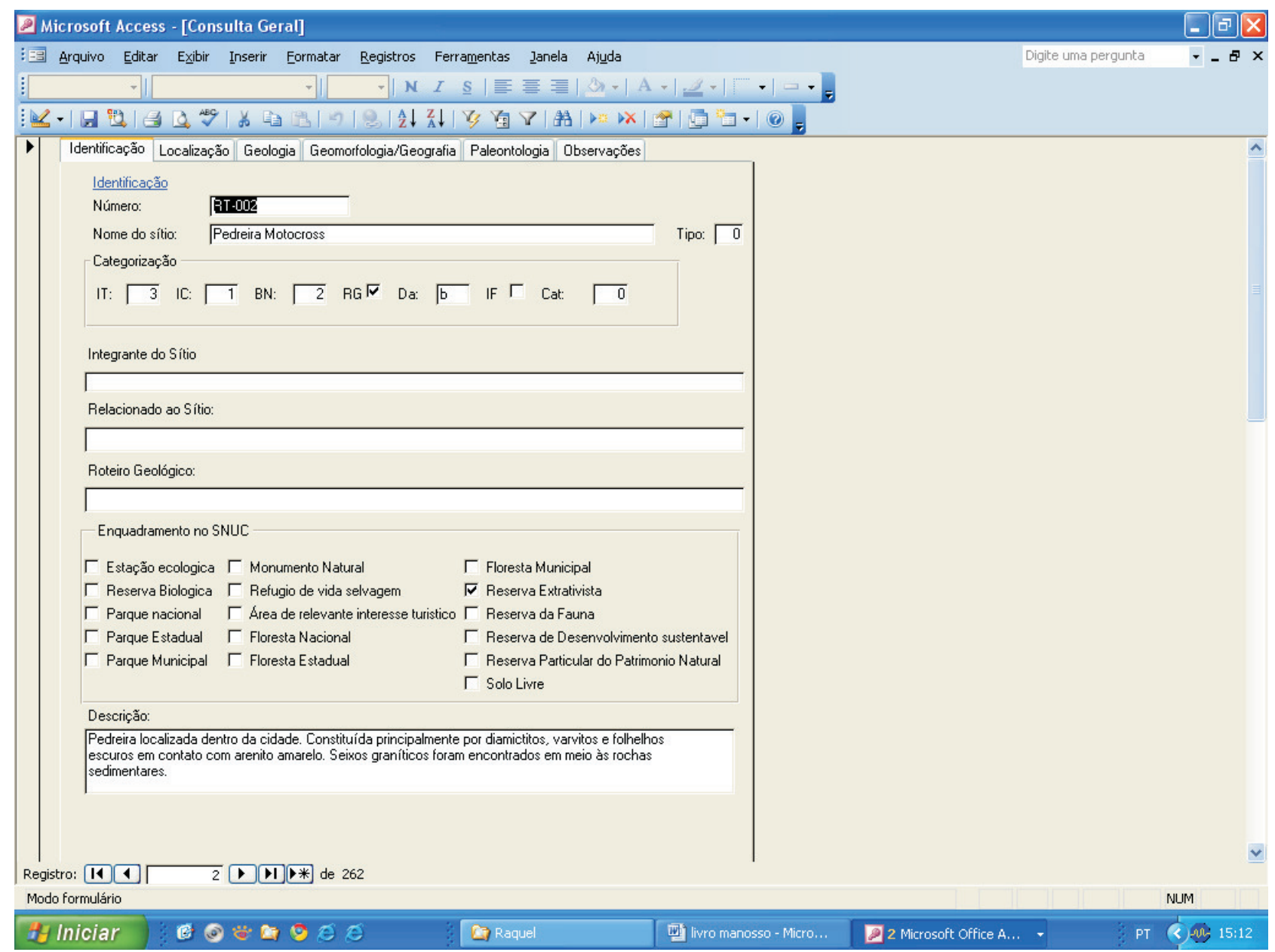

Figura 15 - Modelo de ficha eletrônica utilizada para alimentar o banco de dados que permite inventariar o patrimônio geológico e paleontológico do estado do Paraná

Antes da definição de ações de conservação, no entanto, a Mineropar experimentou disseminar conhecimento, o que a permitiu entender que, em se tratando de monumentos naturais, membros de uma dada população instruídos e educados para a valoração de um monumento geológico adquirem rapidamente o sentido de sua preservação.

Dessa maneira, para que servisse de elementos concretos para a própria disseminação do conhecimento, a Mineropar confeccionou e colocou à disposição de turistas e potenciais turistas, os seguintes produtos: (a) painéis geológicos; (b) folhetos geológicos e (c) roteiros geoturísticos, os quais foram disponibilizados tanto fisicamente quanto digitalmente.

\subsubsection{Painéis e folhetos geológicos}

Os painéis e folhetos servem como material de distribuição local nos sítios geoturísticos, despertando a atenção de turistas para o patrimônio geológico e a necessidade de cuidados com sua preservação e conservação. O conteúdo dos painéis e folhetos fornece explicações geológicas que abrangem, por exemplo, áreas maiores como é o caso de todo o território do município de Tibagi (Sítio Geológico de Tibagi); de áreas mais restritas, que podem englobar porções de um ou mais municípios, por exemplo, o Parque Estadual de Vila Velha (Sítio Geológico Parque Estadual de Vila Velha), ou tão somente afloramentos notáveis, como, por exemplo, o Sítio Geológico Estrias Glaciais de Witmarsum e até uma paisagem específica, como a Serra do Mar.

A observação continuada do programa permitiu concluir que os produtos gerados têm tido grande eficácia para a divulgação do patrimônio geológico e a disseminação da informação geocientífica.

A implantação dos painéis seguiu a experiência do Projeto "Caminhos Geológicos" do DRM-RJ. No estado do Paraná foram implantados pela Mineropar 48 painéis em 21 diferentes geossítios, quase todos com dimensões de $200 \mathrm{~cm} \times 120 \mathrm{~cm}$ (Figura 16). Nesses painéis, confeccionados com adesivo de alta aderência sobre chapa metálica, está descrita a geologia e a geomorfologia do local de interesse, bem como aspectos relevantes do ponto de vista turístico. 


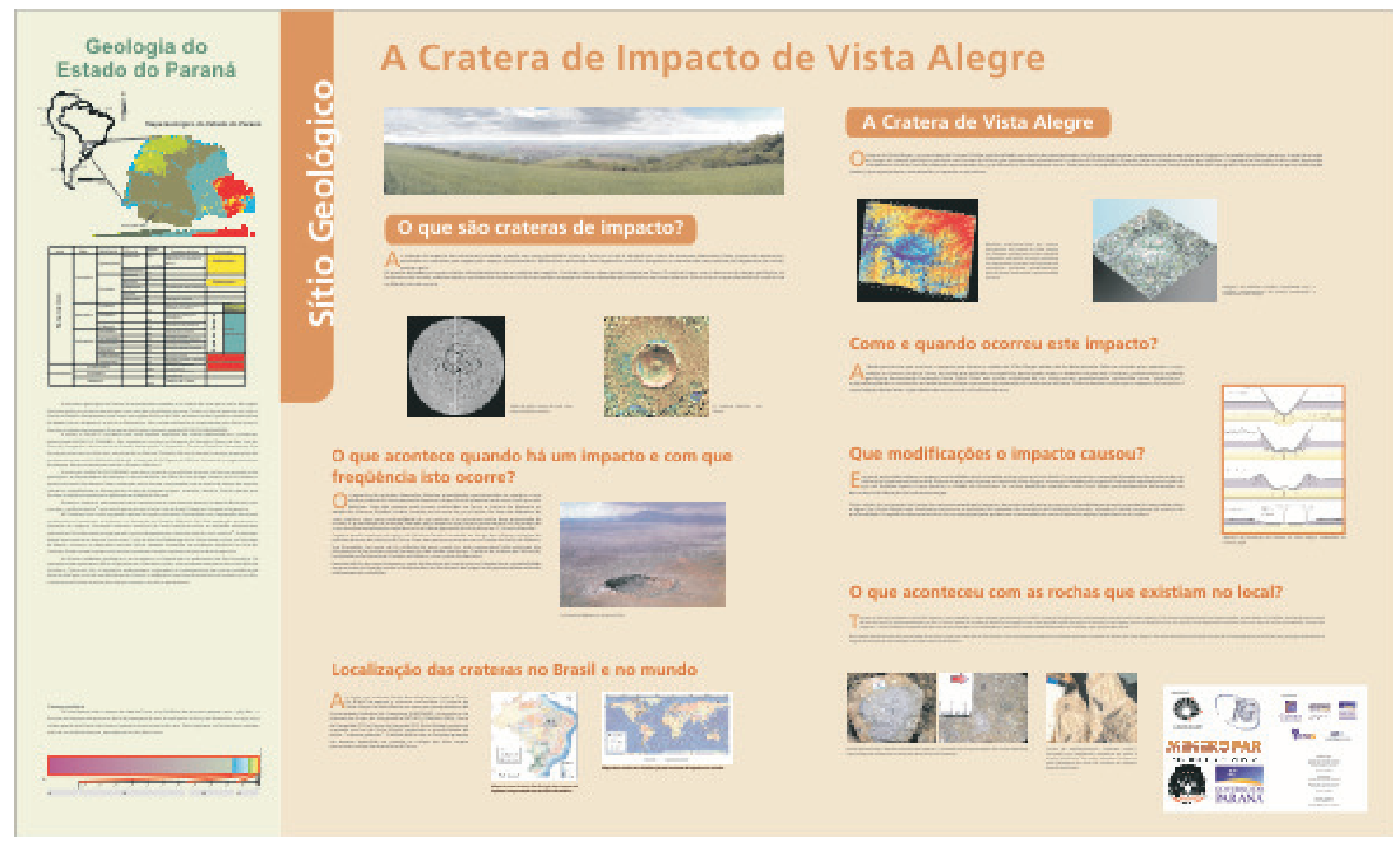

Figura 16 - Exemplo de Painel Geológico. Sítio geológico Cratera de Impacto de Vista Alegre, município de Coronel Vivida - PR.

Por sua vez, os folhetos geológicos estão relacionados aos painéis, contendo as mesmas informações, ou seja, os folhetos permitem que o visitante tenha em mãos as informações do painel, permitindo que as leve após sua visita ao sítio. Por outro lado, o folheto tem servido como material que desperta a atenção de potenciais turistas que ainda não visitaram determinado sítio, nesse caso servindo inicialmente como elemento de propaganda e estímulo tanto quanto de informação.

$\mathrm{Na}$ elaboração, tanto dos painéis quanto dos folhetos, foram tomados cuidados para o correto dimensionamento do volume de informações, para fazer com que o texto prenda a atenção do usuário. Para tanto foi necessário definir uma adequada densidade de informações, evitando-se o "didatismo" e que o conteúdo exposto apresente uma redução de conteúdo para torná-lo simples demais.

\subsubsection{Roteiros Geoturísticos}

São roteiros geológicos direcionados para a educação e para o turismo. Devido a dificuldades em atrair o cidadão leigo em geociências diretamente para roteiros geológicos/geoturísticos específicos, uma boa alternativa é compor roteiros adaptados a roteiros turísticos já implantados e em funcionamento, como fator de agregação de valor. Tal estratégia foi assumida pela Mineropar que a considera eficiente, havendo inclusive a implantação de alguns roteiros para o atendimento de demandas de cursos de capacitação para um público bem diverso, como professores da rede de ensino médio e fundamental, guias e condutores de turismo e sociedade em geral.

Um dos exemplos mais didáticos trata-se do "Roteiro Geoturístico de Curitiba" (Liccardo et al. 2008), publicado em forma livro guia, cujo conteúdo abrange diversos pontos turísticos notáveis da cidade onde a geologia e/ou a geomorfologia constituem fator determinante da visitação, como por exemplo antigas pedreiras transformadas em parques municipais, que constituem geossítios científicos importantes.

Outros roteiros que podem ser mencionados, como importante experiência cognitiva e científica, são aqueles denominados de "Geoturismo na Rota dos Tropeiros" localizada na Bacia do Paraná e nos Campos Gerais no Paraná e que abrange um produto turístico consolidado no estado; "Geoturismo no karst paranaense", que se trata de um produto adaptado a três circuitos turísticos na região metropolitana de Curitiba e que, inclusive, aproveita para mostrar a problemática da ocupação urbana do karst, região reconhecidamente frágil do ponto de vista geotécnico.

\subsubsection{Divulgação e Conservação}

A divulgação do patrimônio geológico para a sociedade, tanto em linguagem científica quanto mais popular, é decisiva para a sua valorização e conservação. Deste modo, a MINEROPAR tem colocado o geoturismo como um programa importante, pois é através dele que a instituição tem conseguido divulgar a geologia para a 
sociedade em geral, sensibilizando-a para a importância da geoconservação.

Ao mesmo tempo o programa aponta para a necessidade de cuidados adicionais com geossítios muito vulneráveis, como determinados afloramentos fossilíferos e de minerais, onde até a coleta, de forma descuidada ou errônea do material para pesquisa, poderia prejudicar de forma irremediável estes geossítios.

Em função desse necessário cuidado e em atenção à necessidade de preservação e valorização de determinados geossítios, a MINEROPAR, em conjunto com prefeituras, encaminhou para o Conselho do Patrimônio Histórico e Artístico do Paraná (CEPHA - PR), órgão vinculado à Secretaria de Estado da Cultura - PR três propostas para a política de tombamento. $O$ primeiro geossítio tombado foi uma pedreira desativada no município de Coronel Vivida (PR) com área aproximada de $10.000 \mathrm{~m} 2$, situada no centro da Cratera de Vista Alegre, astroblema com diâmetro de 9,5km, onde afloram estruturas que comprovam a colisão de um corpo celeste com a Terra (Crósta et al. 2011). Além da importância para a geoconservação, este tombamento causou a valorização do referido geossítio com a formalização de projetos de infraestrutura para receber visitantes. O outro geossítio tombado é um lajeado de arenito (Grupo Itararé) com $50 \mathrm{~m} 2$ (Figuras 17 e 18), onde estão impressas estrias glaciais formadas durante a glaciação permocarbonífera na Bacia do Paraná, denominada de "Estrias Glacias de Witmarsum", já transformada em produto turístico e com medidas de geoconservação tomadas pela própria comunidade. 0 terceiro sítio tombado pelo CEPHA igualmente é um lajeado de arenito, pertencente à Formação Furnas (Bacia do Paraná) na região da serrinha de São Luiz do Purunã, onde estão impressos rastros de vermes (icnofósseis) bastante preservados e que possuem grande interesse paleontológico. Há um quarto geossítio paleontológico em processo de tombamento que é um importante afloramento de fósseis de pterossauros em Cruzeiro do Oeste - PR.

Portanto, em geoconservação, o programa tem atuado na política convencional, ou seja, a dos processos de tombamento vinculados a instituições governamentais. A experiência mostrou que para os geossítios que não estejam em unidades de conservação o regime de tombamento é uma boa política de valorização e preservação do geossítio.

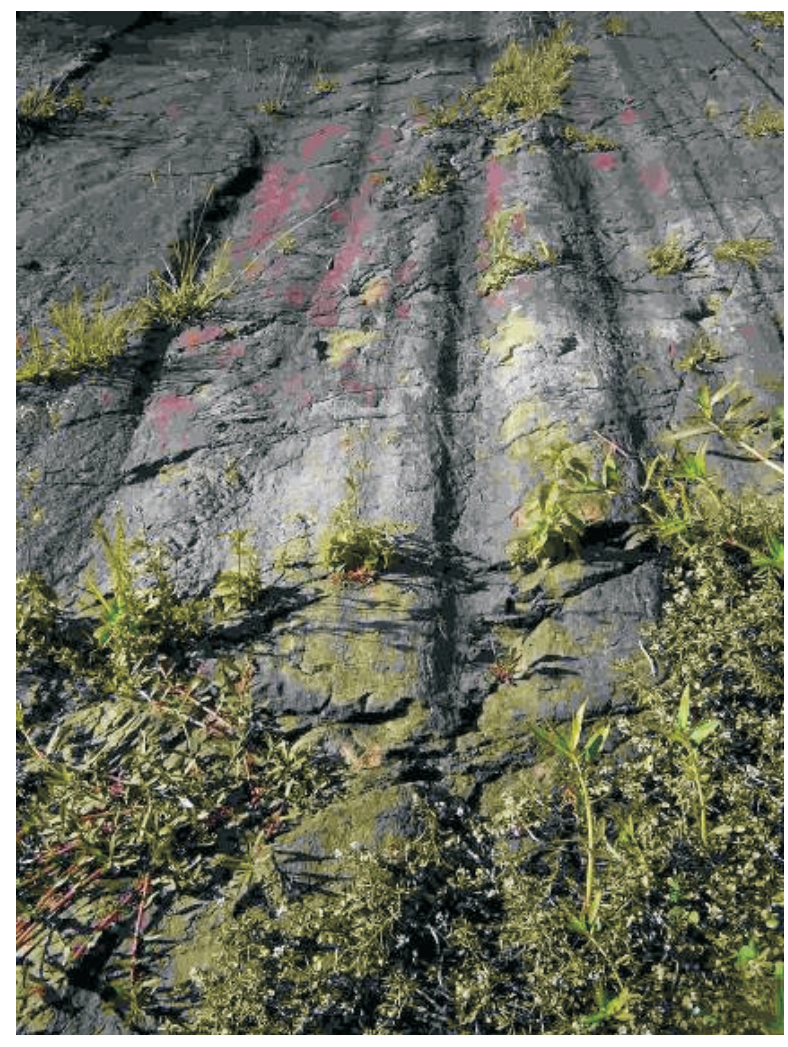

Figura 17 - Estrias Glaciais de Witmarsum. Afloramento tombado pelo CEPHA-PR

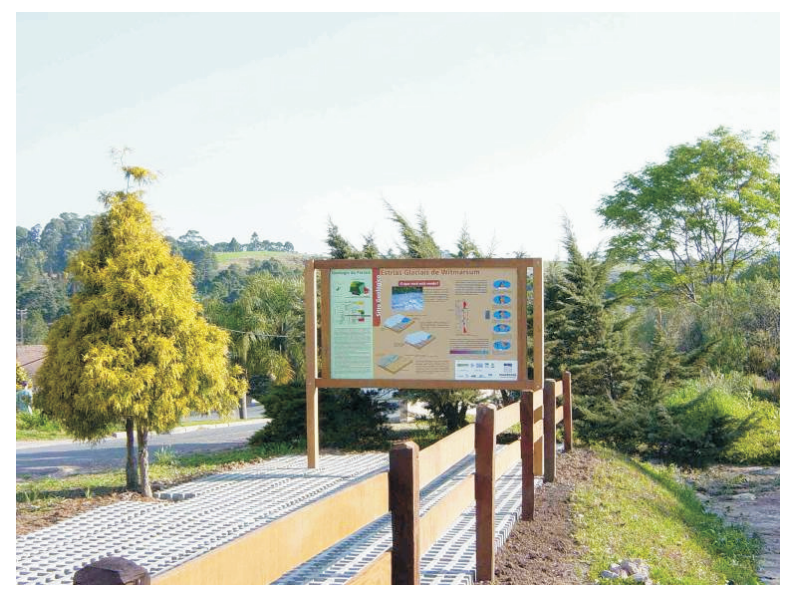

Figura 18 - Estrutura implantada para a conservação e divulgação do geossítio. 


\subsection{Caminhos Geológicos da Bahia}

O Projeto Caminhos Geológicos da Bahia foi o resultado de reuniões informais mantidas durante o ano de 2002 por geólogos da PETROBRAS e da CPRM - Serviço Geológico do Brasil. Uma vez que alguns desses geólogos eram sócios da Sociedade Brasileira de Geologia e mesmo membros da diretoria do Núcleo Bahia/Sergipe, esta Sociedade também passou a participar do projeto.

O plano inicial do projeto era viabilizar a implantação de cerca de 30 painéis distribuídos ao longo das rodovias BR-324 (Salvador- Feira de Santana), BR101 (Conceição do Jacuípe - Alagoinhas), BR-110 (Simões Filho-Alagoinhas) e BA-093 (Entre Rios - Pojuca). Estas rodovias propiciariam a divulgação dos conhecimentos básicos sobre a Bacia Sedimentar do Recôncavo. Adicionalmente seriam colocadas cerca de 50 placas secundárias para sinalização dos painéis.

Para a execução deste projeto, foi formada uma comissão composta de um coordenador geral, um conselho editorial com cinco membros e uma equipe de produção e apoio com três membros; os autores das informações a serem apresentadas nas placas seriam convidados de entidades externas ao projeto. Posteriormente o objetivo do projeto foi ampliado para a confecção de 36 placas a serem implantadas até o ano de 2009, em locais distribuídos por todo o estado da Bahia.

A primeira placa foi inaugurada no dia 4 de abril de 2004, entre o Mercado Modelo e o Elevador Lacerda, em Salvador (Figuras 19 e 20).

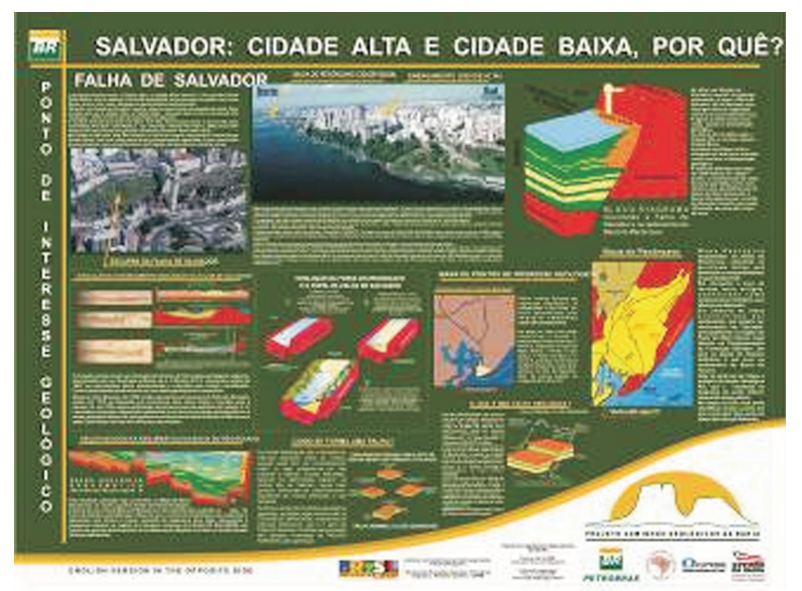

Figura 19-Painel dedicado à falha de Salvador..

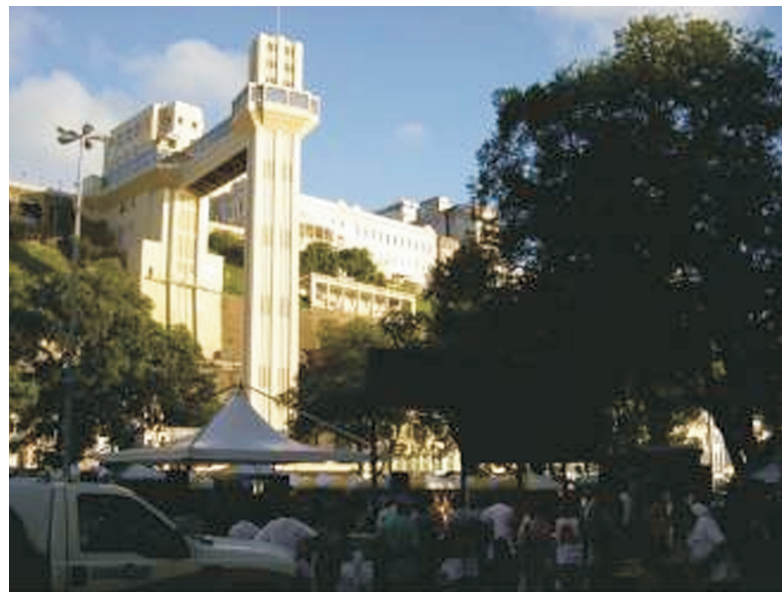

Figura 20 - Elevador Lacerda que liga os blocos alto e baixo da falha.

Antes da inauguração uma equipe desceu de "rappel" o Elevador Lacerda. A CPRM- Serviço Geológico do Brasil produziu e distribuiu um folder resumindo as informações contidas no painel interpretativo.

A segunda placa foi inaugurada alguns meses depois na fonte do Dique do Tororó. De acordo com o folder distribuído, as águas da fonte do Dique teriam sido utilizadas desde o século XVIII e a fonte seria de um tipo específico (fonte de vale). Os autores convidados para a elaboração desta placa foram professores do Instituto de Geociências da Universidade Federal da Bahia.

Em abril de 2005 foram inauguradas mais duas placas: no Serrano, na cidade de Lençóis, e no Posto Pai Inácio em frente ao morro homônimo, no município de Palmeiras. As Figuras 21 e 22 reproduzem o folder distribuído na ocasião.
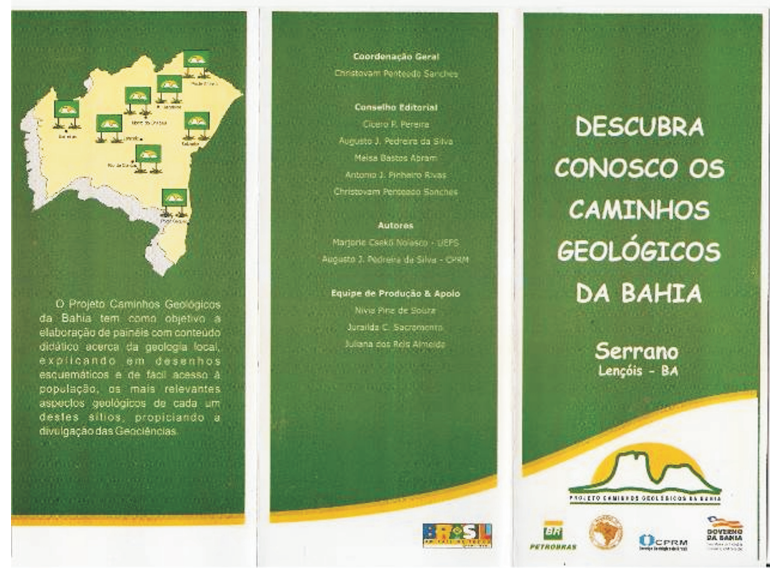

Figura 21 - Frente do folder patrocinado pela CPRM e distribuído durante a inauguração da placa do Serrano, em Lençóis, Bahia.

${ }^{1}$ Luiz Rogério Bastos Leal e Joana Angélica Luz

${ }^{2}$ A elaboração do texto da placa do Serrano contou com a colaboração da Prof. Marjorie C. Nolasco da Universidade Estadual de Feira de Santana e o da placa do Posto Pai Inácio foi redigido pelo geólogo Antonio Jorge Magalhães, da Petrobras, em colaboração com o geólogo Augusto J. Pedreira da CPRM. 


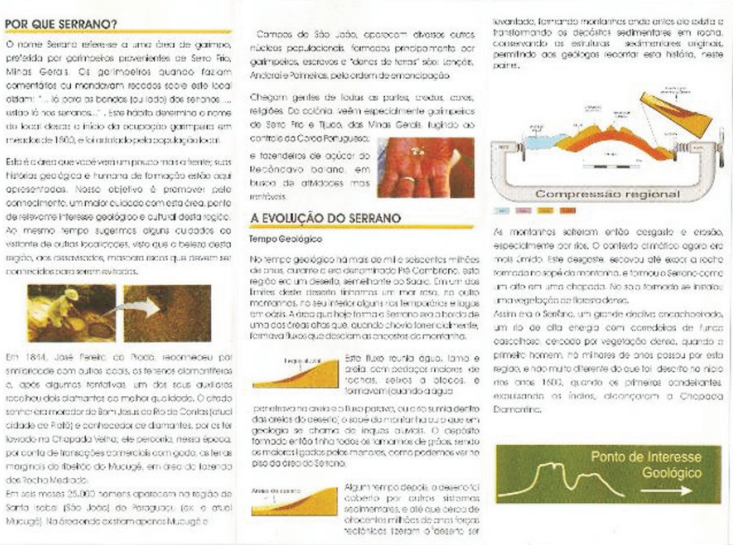

Figura 22 - Verso do folder patrocinado pela CPRM e distribuído durante a inauguração da placa do Serrano, em Lençóis, Bahia.

Finalmente, em junho de 2005, foi implantada uma última placa, dedicada à deriva continental. O local escolhido foi o Aeroclube Plaza Show, um "Shopping Center", localizado à beira-mar na praia de Piatã (Salvador). As Figuras 23 e 24 mostram o folder distribuído na inauguração da placa.
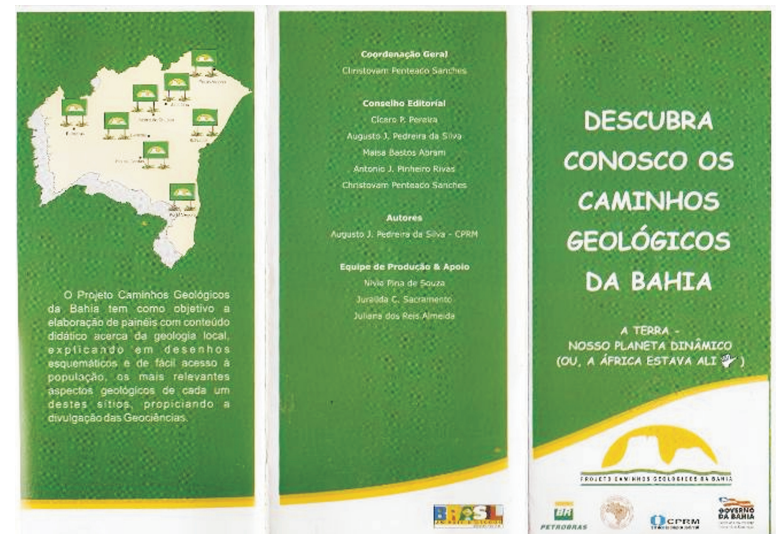

Figura 23 - Frente do folder, patrocinado pela CPRM e distribuído durante a inauguração da placa no Aeroclube Plaza Show.

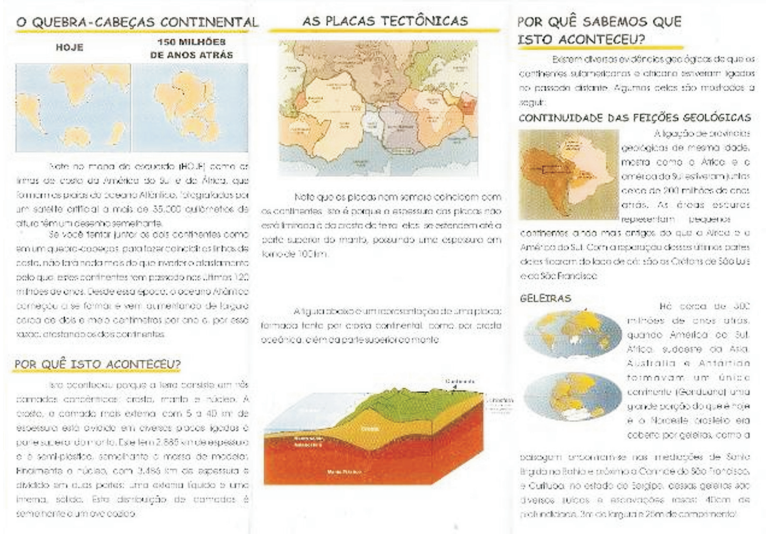

Figura 24 - Verso do folder, patrocinado pela CPRM e distribuído durante a inauguração da placa no Aeroclube Plaza Show.
Apesar da assinatura de um memorando de entendimento entre os representantes da PETROBRAS, SBG e CPRM por ocasião da inauguração da primeira placa, o projeto não teve apoio institucional. Por causa disso, nunca houve contatos prévios com as comunidades onde as placas seriam instaladas.

Em consequência, as placas foram sendo destruídas, removidas ou abandonadas: a placa da Falha de Salvador, já bastante deteriorada foi removida pela PETROBRAS para consertos; a placa do Dique do Tororó, simplesmente desapareceu; a placa do Serrano foi destruída pela comunidade; a do morro do Pai Inácio, derrubada por uma tempestade e não recolocada e, finalmente, a da deriva Continental, abandonada e destruída juntamente com o Aero Clube Plaza Show.

O projeto tinha outros desdobramentos previstos, como a "Cidade da Geologia" e apoio à confecção de material de divulgação da geologia para ser utilizado durante o 43을 Congresso Brasileiro de Geologia. Para o desenvolvimento do primeiro projeto foi escolhida a cidade de Jacobina, em 2002, por suas características regionais estratigráficas, sedimentológicas, estruturais, petrológicas, geoeconômicas e tradição mineira. Este projeto, sequer saiu do papel.

Finalmente, o último projeto consistiu na preparação de papeis de bandeja para serem distribuídas nos "Shopping Centers" e outros estabelecimentos da cidade de Aracaju, durante a realização do 43 Congresso Brasileiro de Geologia. Foram preparados cinco modelos ilustrando fenômenos geológicos (Figura 25), e financiados por empresas privadas, com os seguintes temas: Terremoto, Tsunami, Vulcão, Petróleo e Gás e O Ciclo da Água.

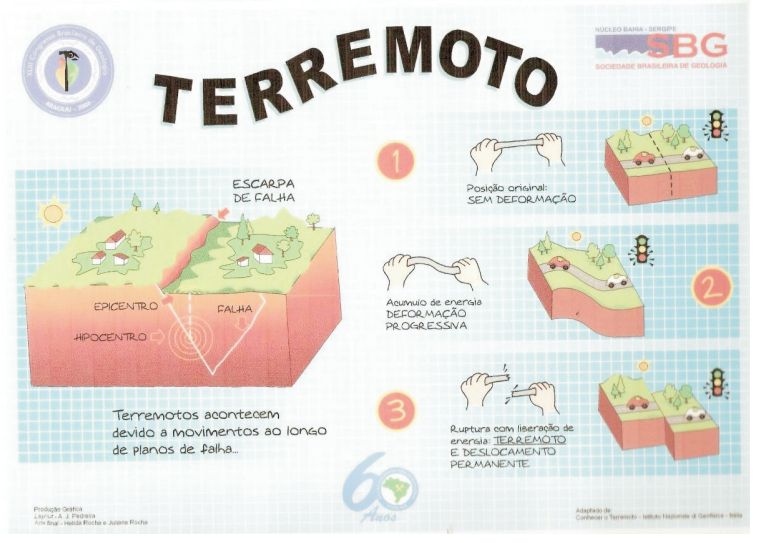

Figura 25 - Papel de bandeja / mini-toalha distribuído durante o 43- Congresso Brasileiro de Geologia, em Aracaju-SE.

O Projeto Caminhos Geológicos da Bahia, mesmo antes da disseminação de conhecimentos acerca de patrimônio geológico, geodiversidade, geoconservação e geoturismo, foi pioneiro neste aspecto na região. Entretanto por falta de apoio federal, estadual ou municipal, foi paralisado, estando em estado latente. Havendo tal apoio ele poderá ser reativado, aproveitando 
a extraordinária geodiversidade do estado da Bahia.

\subsection{Monumentos Geológicos do Rio Grande do Norte}

O Instituto de Desenvolvimento Sustentável e Meio Ambiente do RN - IDEMA/RN criou, no início de 2006, o projeto Monumentos Geológicos do Rio Grande do Norte e a partir daí firmou um convênio com a PETROBRAS/CEFET/FUNCERN, estabelecendo para a sua execução uma parceria em conjunto com a CPRM Serviço Geológico do Brasil e a Universidade Federal do Rio Grande do Norte - UFRN, no intuito de contar um pouco da história geológica potiguar através de painéis explicativos.

A parceria com geólogos, professores e pesquisadores da UFRN, CPRM (Núcleo de Natal NANA), PETROBRAS e CEFET (atual IFRN) permitiu o levantamento dos dados e a geração das informações científicas para a confecção dos painéis interpretativos úteis para levar a sociedade o entendimento acerca da evolução geológica do Rio Grande do Norte.

O objetivo do projeto foi propiciar a divulgação das geociências, dos seus monumentos, para proporcionar uma série de fatores, como: i) reconhecere preservar os monumentos geológicos do Estado; ii) divulgar o conhecimento geológico entre as comunidades; iii) fortalecer o potencial geoturístico da região e iv) incentivar o desenvolvimento socioeconômico relacionado com a geologia.

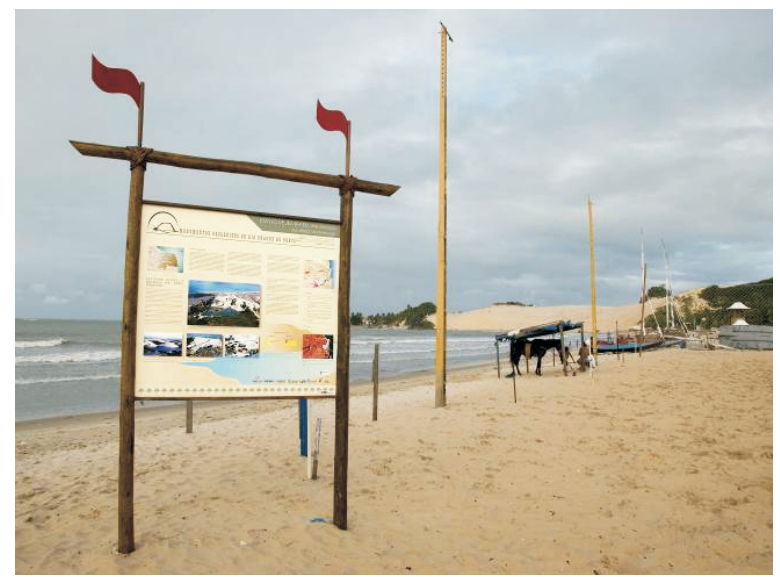

Figura 26 - Exemplos de sítios geológicos escolhidos para sinalização geoturística no RN. Dunas de Jenipabu (em Extremoz). Fotos: Alenuska.

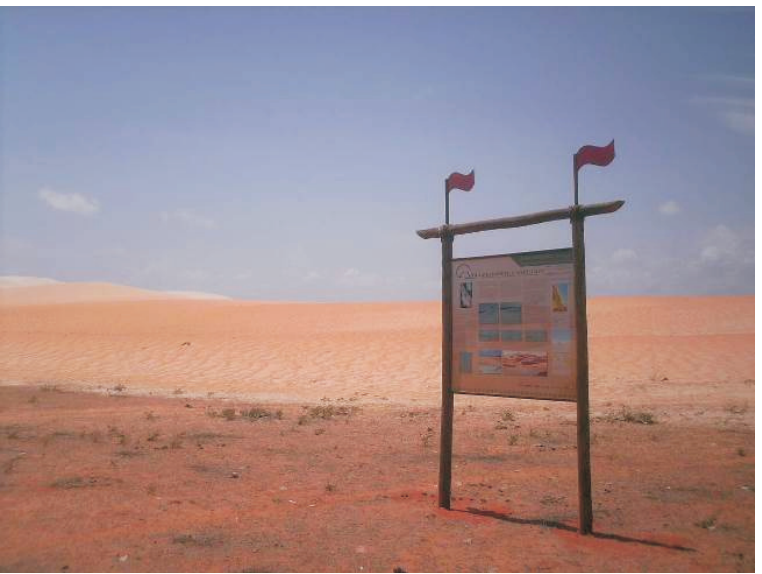

Figura 27 - Exemplos de sítios geológicos escolhidos para sinalização geoturística no RN. Dunas do Rosado (em Porto do Mangue). Foto: IDEMA.

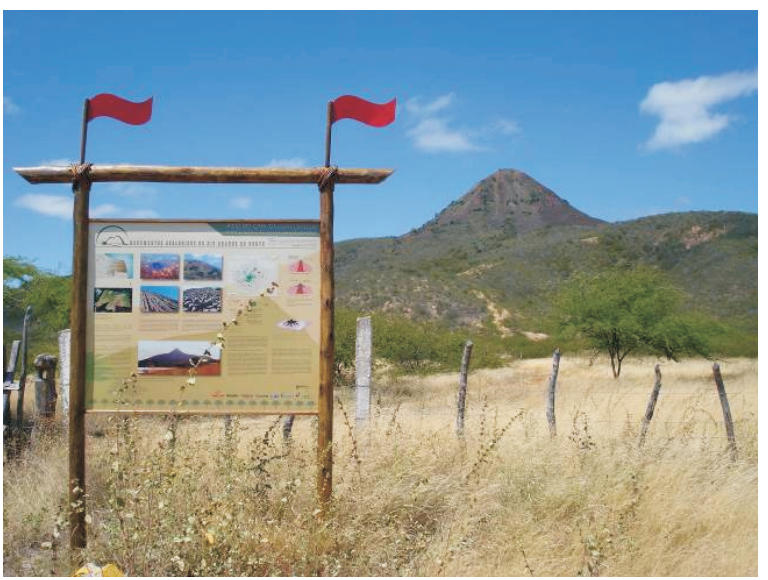

Figura 28 - Exemplos de sítios geológicos escolhidos para sinalização geoturística no RN. Pico do Cabugi (em Angicos). Foto: Marcos Nascimento.

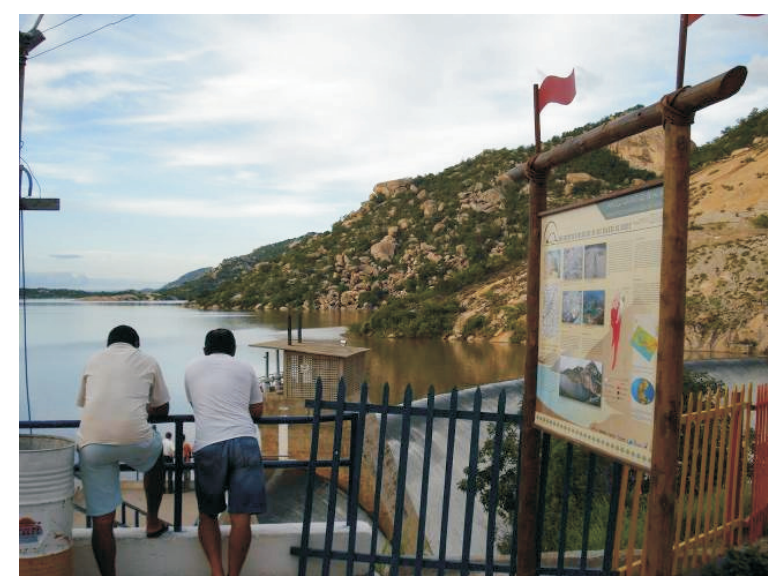

Figura 29 - Exemplos de sítios geológicos escolhidos para sinalização geoturística no RN. Granito de Acari (em Acari). Foto: Marcos Nascimento. 
A meta foi confeccionar painéis informativos com conteúdo didático sobre geologia, geomorfologia, petrologia, paleontologia, arqueologia e espeleologia, contendo nestes um título, mapa de localização, explicação em um texto em português de fácil entendimento (e uma versão resumida em inglês) e os aspectos da evolução geológica de cada ponto selecionado.

No primeiro momento do projeto, foi selecionado em conjunto pelo IDEMA/RN, CPRM e UFRN, um total de 16 pontos de interesse geológico para colocação dos painéis. Os monumentos escolhidos foram:

a) No Litoral: Morro do Careca, Parque das Dunas, Dunas de Jenipabu (Figura 26), Dunas do Rosado (Figura 27), Arenitos Praiais, Recifes de Corais e Falésias de Pipa;

b) No Interior: Pico vulcânico do Cabugi (Figura 28), Caverna de Pedra de Martins, Granito de Acari (Figura 29), Lajedo de Serra Caiada, Lajedo de Soledade, Tanques Fossilíferos de São Rafael, Mina Brejuí, Pegmatitos de Parelhas e Poço 9-MO-13-RN (primeiro poço produtor de óleo na Bacia Potiguar).

Paralela à implantação desses painéis foram também elaborados cartões-postais úteis para uma divulgação mais ampla desses monumentos geológicos. Essa iniciativa, pioneira no Brasil, está recebendo elogios de pessoas interessadas no assunto e coordenadores de projetos co-irmãos. Além disso, também foram elaborados os painéis itinerantes, contendo as mesmas informações e imagens dos painéis colocados ao lado dos monumentos geológicos. Estes servem para levar à sociedade todas as informações sobre cada monumento sendo muito utilizado em feiras e exposições pelo Estado do Rio Grande do Norte.

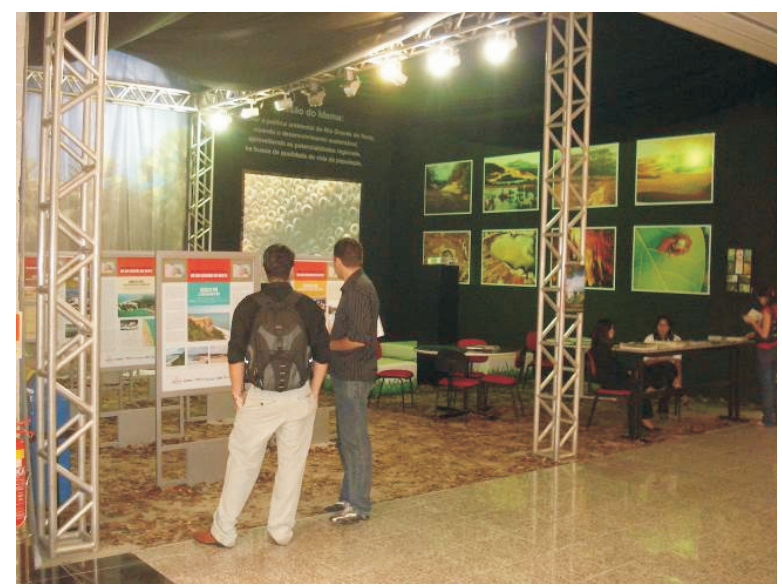

Figura 30 - Outras formas de divulgação das geociências no âmbito do Projeto Monumentos Geológico do Rio Grande do Norte. Espaço Ecológico criado em um Shopping de Natal, expondo as diferentes ações realizadas pelo IDEMA no Estado, com destaque para a Exposição Monumentos Geológicos do Rio Grande do Norte e seus painéis itinerantes.

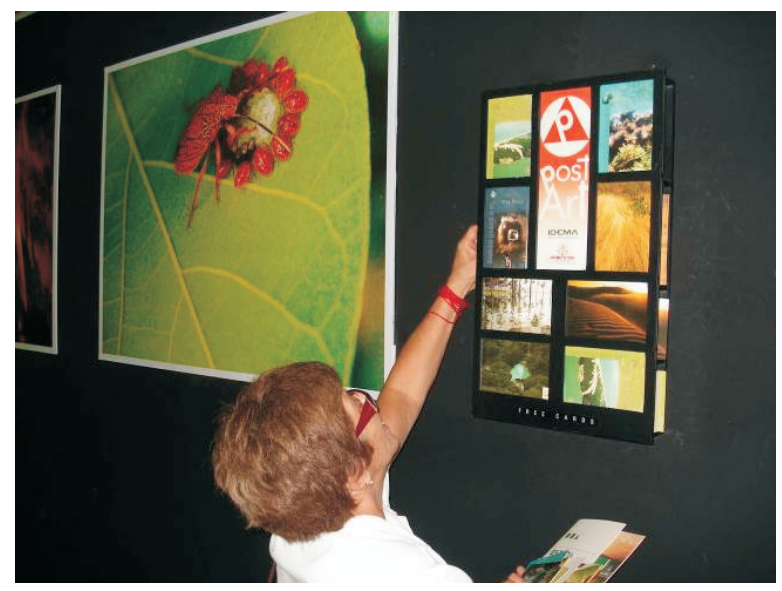

Figura 31 - Outras formas de divulgação das geociências no âmbito do Projeto Monumentos Geológico do Rio Grande do Norte. Visitante admirando os diferentes cartões-postais com imagens da geodiversidade potiguar. Foto: Marcos Nascimento.

A exemplo de estados como Rio de Janeiro, Paraná e Bahia, o Rio Grande do Norte tornou-se o quarto Estado brasileiro a criar um programa específico para proteção dos monumentos geológicos e divulgação destes para a sociedade.

\subsection{Projeto Monumentos Geológicos do Estado de São Paulo}

As primeiras ações bem sucedidas de sinalização/divulgação do patrimônio natural geológico no Estado de São Paulo ocorreram com a criação dos Parques Municipais "Rocha Moutonnée" (1991) e "Varvito de Itu" (1995), localizados respectivamente nas cidades paulistas de Salto e Itu.

Após devidamente estudados (Rocha-Campos, 2002a, 2002b) e conservados, a etapa de divulgação/sinalização desse patrimônio contou com a elaboração de painéis geológicos explicativos e com placas rodoviárias indicando a atração turística (Figuras 32, 33, 34, 35, 36, 37, 38 e 39).

Atualmente, o Parque da Rocha Moutonneé passa por reformas que ampliarão seu potencial turístico e de divulgação da geodiversidade. Com recursos oriundos do Departamento de Apoio ao Desenvolvimento das Estâncias (DADE), da Secretaria Estadual de Turismo, estão previstas, entre outras melhorias, a adequação das normas de acessibilidade, construção de auditório, praça cívica, painéis museográficos, sinalização e totens explicativos das atrações, bem como a implantação de réplicas de dinossauros robotizados.

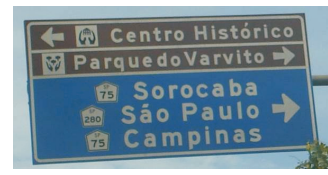

Figura 32 - Sinalização/divulgação do Monumento Geológico Varvito de Itu: Painel Rodoviário (fonte: acervo IG/SMA - dez. 2009) 


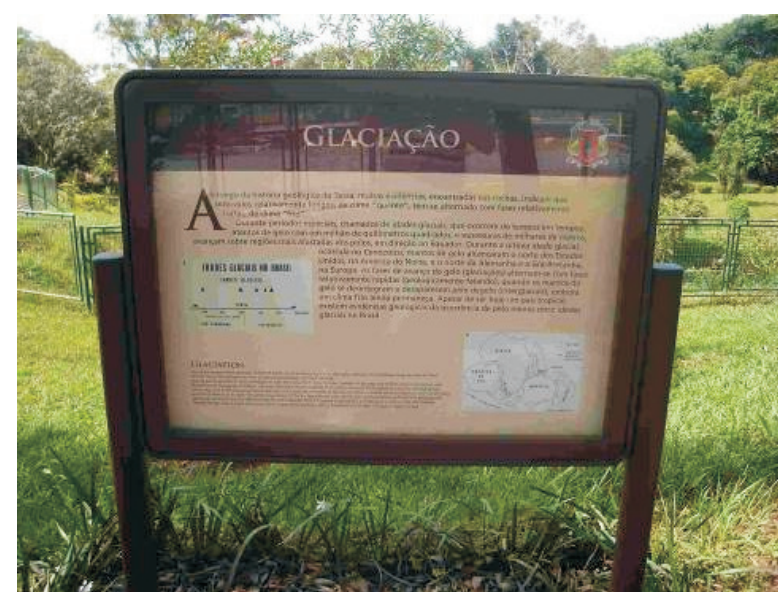

Figura 33 - Sinalização/divulgação do Monumento Geológico Varvito de Itu: Painéi geológico referente ao geossítio Varvito de Itu, existente no Parque Municipal do Varvito, Itu (SP) (Fonte: Acervo IG/SMA-dez. 2009).

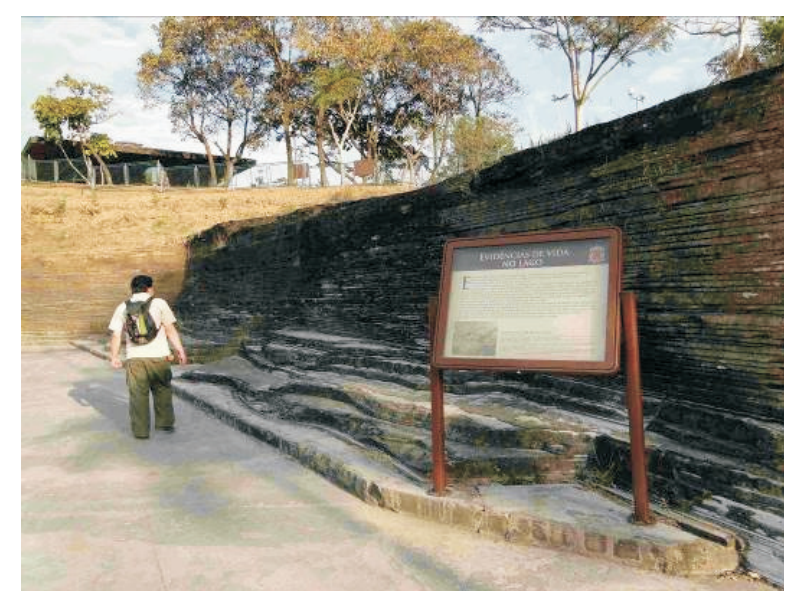

Figura 34 - Sinalização/divulgação do Monumento Geológico Varvito de Itu: Painéi geológico referente ao geossítio Varvito de Itu, existente no Parque Municipal do Varvito, Itu (SP) (Fonte: Acervo IG/SMA-dez. 2009).

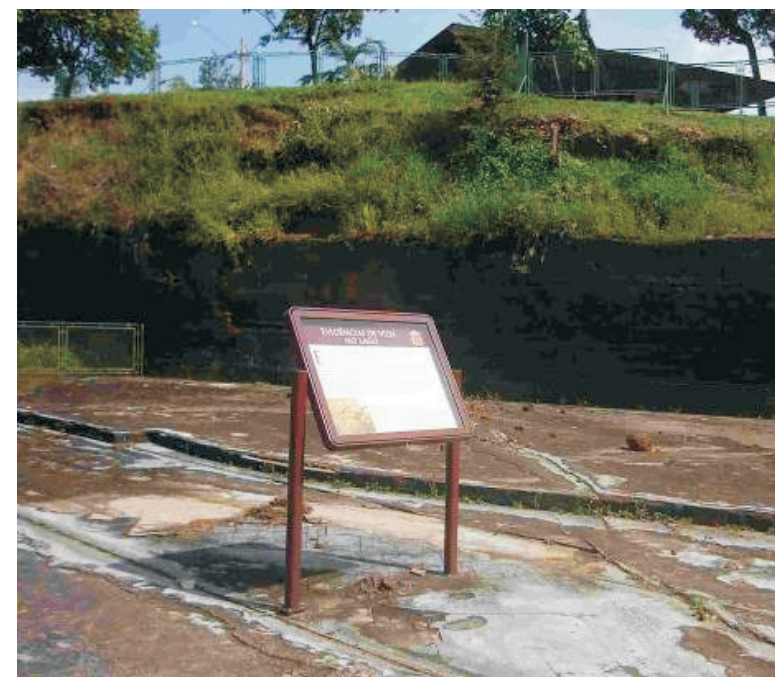

Figura 35 - Sinalização/divulgação do Monumento Geológico Varvito de Itu: Painéi geológico referente ao geossítio Varvito de Itu, existente no Parque Municipal do Varvito, Itu (SP) (Fonte: Acervo IG/SMA-dez. 2009).

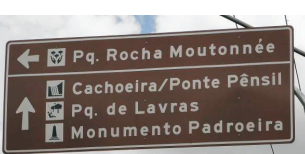

Figura 36 - Sinalização / divulgação do Monumento Geológico Rocha Mountonneé: Painel Rodoviário (fonte: acervo IG/SMA dez. 2009).

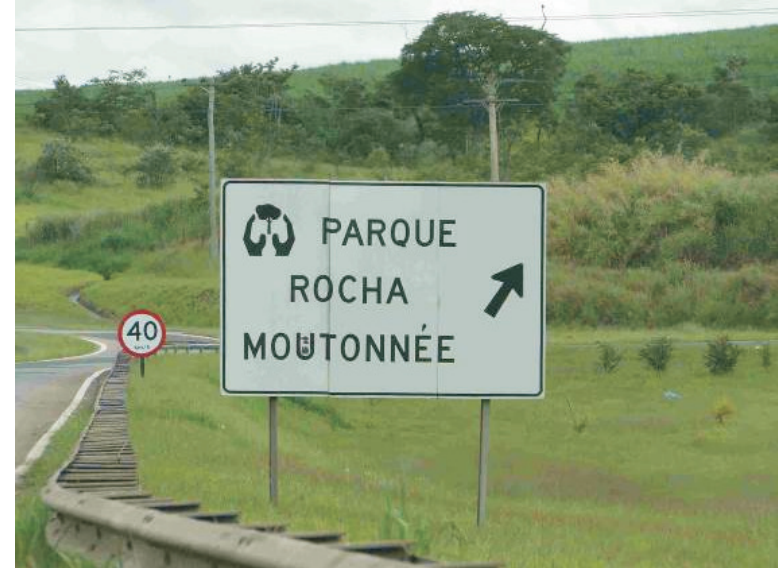

Figura 37 - Sinalização / divulgação do Monumento Geológico Rocha Mountonneé: Painel Rodoviário (fonte: acervo IG/SMAdez. 2009).

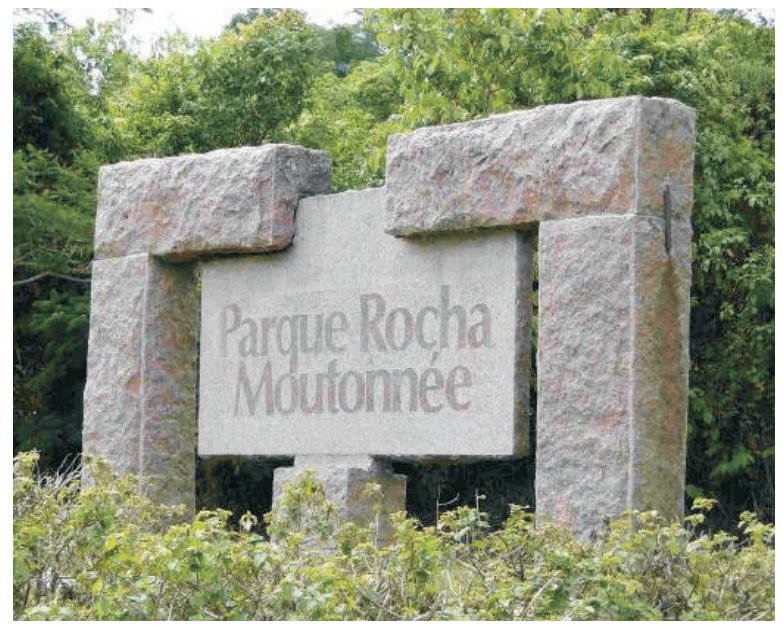

Figura 38 - Sinalização / divulgação do Monumento Geológico Rocha Mountonneé: Totem de entrada do Parque Municipal Rocha Mountonneé, Salto (SP), confeccionado com o famoso granito róseo de ltu.

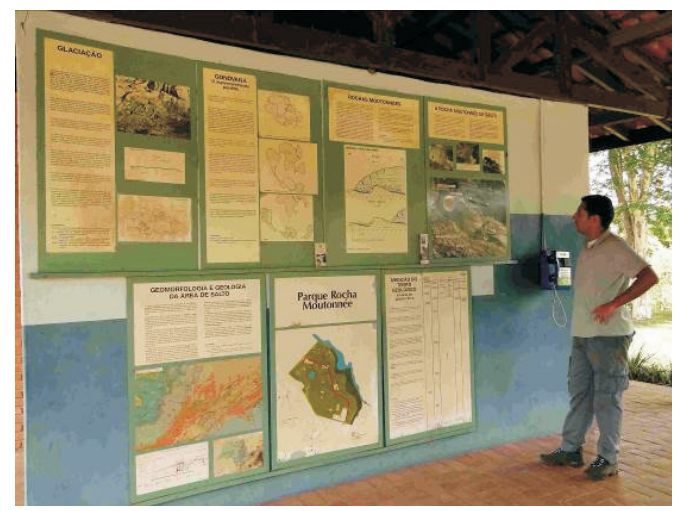

Figura 39 - Sinalização / divulgação do Monumento Geológico Rocha Mountonneé: Painéis geológicos (Fonte: Acervo IG/SMA -dez. 2009). 
No governo do Estado, as primeiras políticas de divulgação do patrimônio geológico também datam da década de setenta, especialmente com a publicação do Decreto Estadual no 11.138/78. Este documento colocava sob a égide da antiga Divisão de Proteção de Recursos Naturais (DPRN) e do Instituto Geológico (IG) as atribuições de manutenção dos "serviços de conservação de monumentos geológicos naturais para fins científicos culturais e turísticos" (artigo 436, VII - grifo nosso). Posteriormente, já na década de oitenta, as ações de divulgação do patrimônio foram reunidas e repassadas definitivamente ao Instituto Geológico, agora integrante da Secretaria de Estado do Meio Ambiente (SMA), por meio da criação da Seção de Monumentos Geológicos (Decretos Estaduais no 24.931/86 [art. 10, III] e $n^{\circ}$ 26.942/87 [art. $1^{\circ}$ ]).

No âmbito da Seção de Monumentos Geológicos foi desenvolvido o Projeto Monumentos Geológicos de São Paulo, importante instrumento criado para a divulgação do patrimônio geológico paulista. 0 projeto foi apresentado no dia 27 de março de 2009, na sede do IG, durante a celebração dos 123 anos de criação da Commissão Geographica e Geológica (CGG) da então Província de São Paulo. Nesta mesma data também se comemora o aniversário do IG, visto que o instituto é oriundo da referida Comissão.

Ainda em andamento, este instrumento tem como principal objetivo promover o registro, o conhecimento, a conservação e a divulgação do patrimônio geológico do Estado de São Paulo, abordando a geodiversidade como arcabouço fundamental da biodiversidade.

Alguns produtos deste projeto voltados especificamente para a divulgação/sinalização do patrimônio geológico são: a sua logomarca, os primeiros marcadores de página da série "Monumentos Geológicos de São Paulo", folderes, bloco de notas, cartões postais, etc. (Figuras 40, 41, 42, 43, 44 e 45).

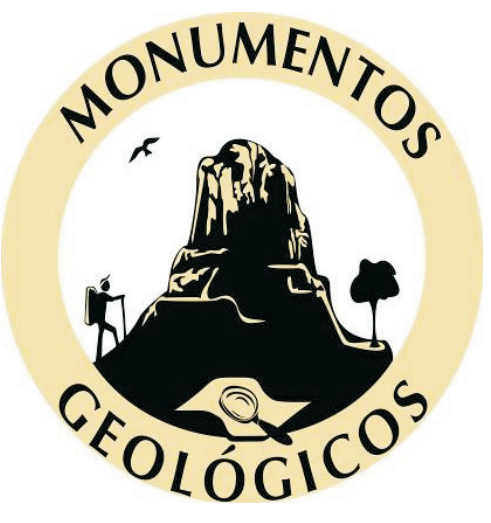

Figura 40 - Primeiros produtos do Projeto Monumentos Geológicos de São Paulo: Logomarca.

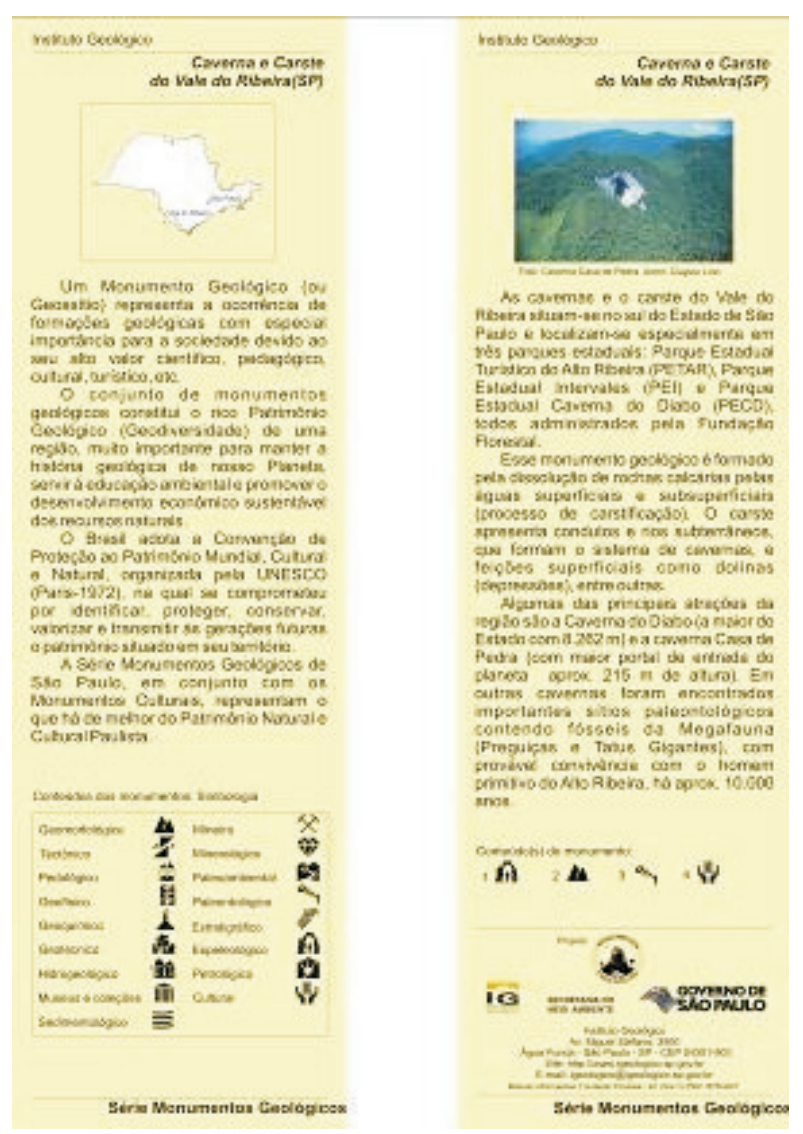

Figura 41 - Primeiros produtos do Projeto Monumentos Geológicos de São Paulo: Marcadores de página.

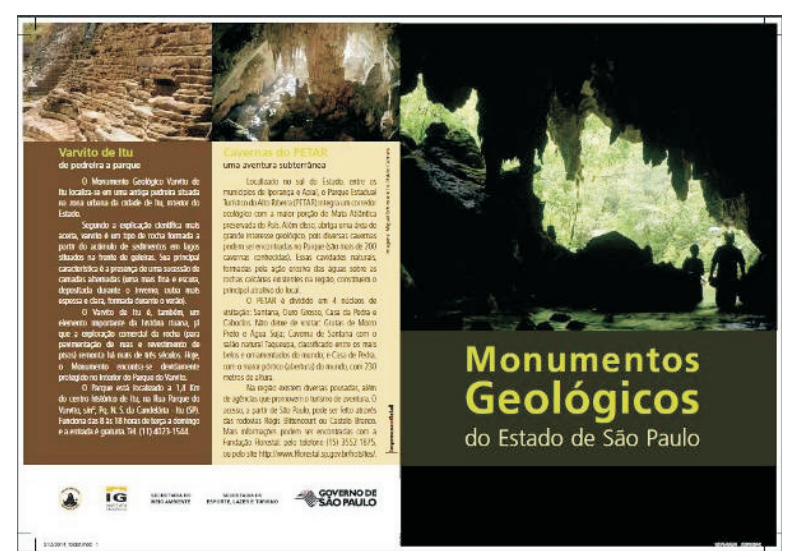

Figura 42 - Primeiros produtos do Projeto Monumentos Geológicos de São Paulo: Folder de divulgação Secretaria de Estado de Lazer e Turismo. 


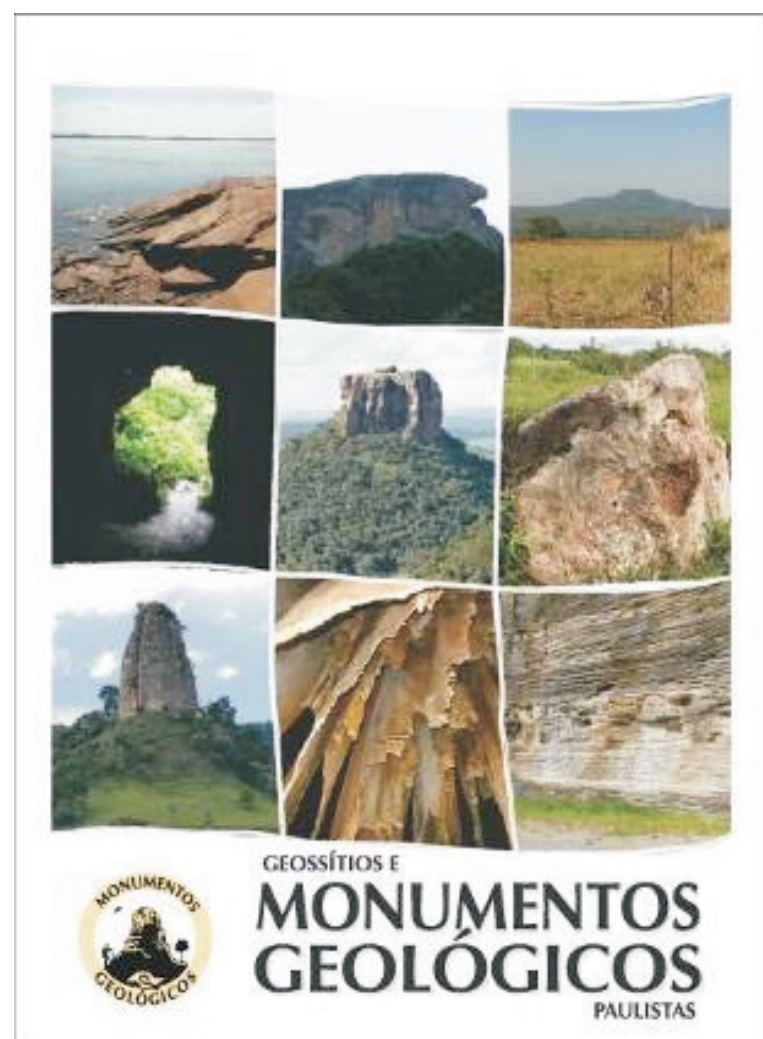

Figura 43 - Primeiros produtos do Projeto Monumentos Geológicos de São Paulo: Bloco de notas.

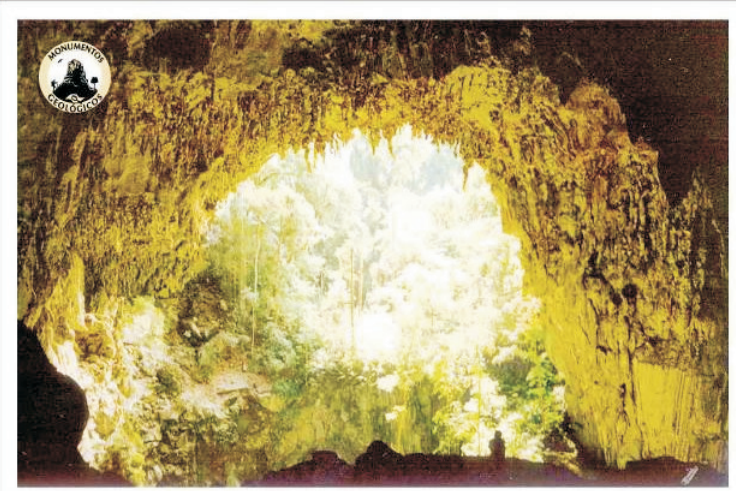

Figura 44 - Primeiros produtos do Projeto Monumentos Geológicos de São Paulo: Cartão postal do Monumento Geológico Carste e Cavernas do PETAR.

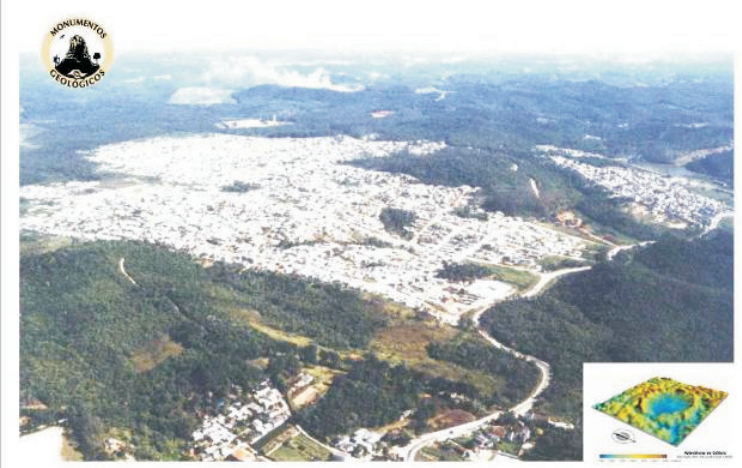

Figura 45 - Primeiros produtos do Projeto Monumentos Geológicos de São Paulo: Cartão postal do Monumento Geológico do Astroblema de Colônia.
No final de 2012, foram lançados os primeiros painéis geoturísticos com o objetivo de divulgar o patrimônio geológico paulista. Trata-se de painéis autoexplicativos e didáticos que contam a origem geológica e geomorfológica do geossítio denominado "Morro do Diabo", localizado no município paulista de Teodoro Sampaio (Figuras 46 e 47). Os painéis reuniram instituições públicas e universitárias paulistas para sua elaboração e implantação

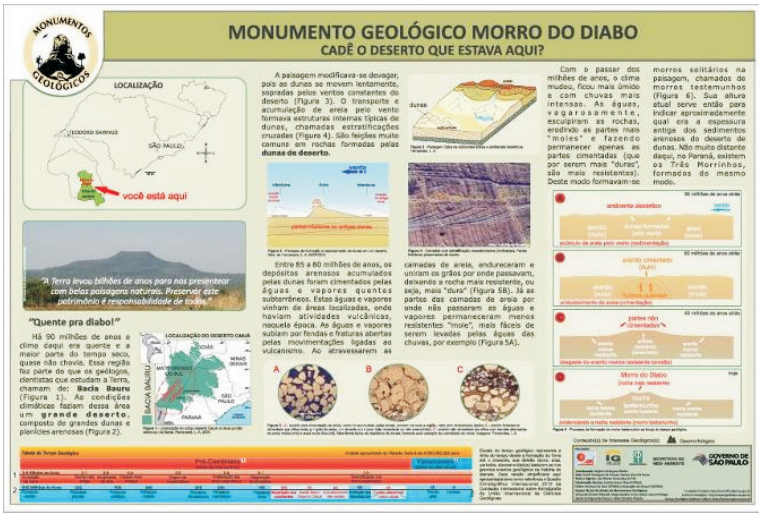

Figura 46 - Primeiros painéis elaborados no âmbito do Projeto Monumentos Geológicos de São Paulo referentes ao geossítio "Morro do Diabo", sito no município de Teodoro Sampaio (SP).

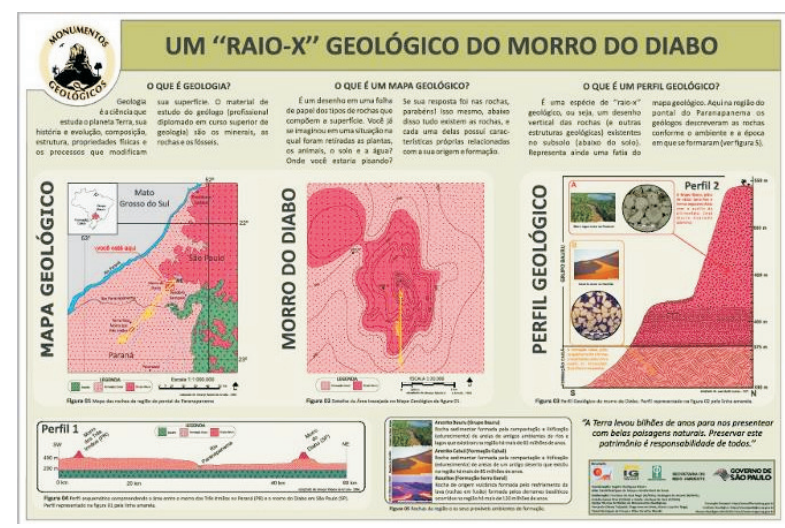

Figura 47 - Primeiros painéis elaborados no âmbito do Projeto Monumentos Geológicos de São Paulo referentes ao geossítio “Morro do Diabo", sito no município de Teodoro Sampaio (SP).

Em 2009 foi criado, por meio da Resolução SMA no 076/2009, o Conselho Estadual de Monumentos Geológicos (CoMGeo-SP), junto à Secretaria de Estado de Meio Ambiente. O CoMGeo-SP, de caráter consultivo, tem com principal objetivo auxiliar, no âmbito da SMA, as ações e atividades que envolvam a pesquisa, conservação e divulgação dos Geossítios e Monumentos Geológicos de São Paulo (grifo nosso). É composto pelo Secretário do Meio Ambiente (que é seu presidente), pelo diretor do IG, pelo chefe da Seção de Monumentos Geológicos (que é o Secretário Executivo) e por outros 16 Conselheiros, reconhecidos pela atuação nos temas relacionados aos Geossítios e Monumentos Geológicos (Figura 48).

Além do Varvito de Itu, e da Rocha Mountonnée, outros quatro geossítios compõe os seis monumentos geológicos declarados pelo CoMGeo-SP até abril de 2013: 
Carste e Caverna do PETAR, Cratera de Colônia, Geiseritos do Anhembi e Pedra do Baú.

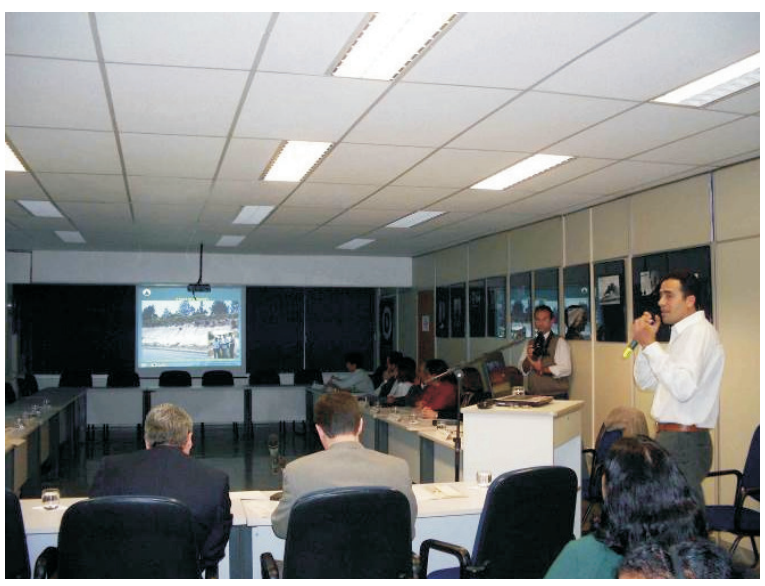

Figura 48-Reunião Ordinária do CoMGeo-SP-Sede SMA/SP.

\section{CONSIDERAÇÕES FINAIS}

Quanto aos aspectos metodológicos, entendese que:

a) para gerar uma ação sistemática de conservação do patrimônio geológico de um território é necessário categorizar os sítios de interesse, apoiando-se no inventário realizado para, então, definir as medidas de conservação, que necessariamente devem seguir uma ordem sequencial.

b) para o desenvolvimento de projetos desta natureza, o método ideal é a implantação dos painéis em decorrência da finalização do inventário do patrimônio geológico local, seja a área de um município ou de todo o estado. Apesar disto, geossítios notáveis no estado do Paraná, de grande relevância geológica e/ou paisagística já comprovada pelo histórico de demanda turística, foram contemplados com os painéis de forma concomitante à confecção do inventário.

c) é fundamental a avaliação pedagógica do material dos painéis, buscando sua continua evolução. Para tanto, conclui-se pela necessidade de solicitar que, tanto leigos no conhecimento geológico quanto profissionais com experiência em redação em geociências, opinem sobre o conteúdo gráfico e textual do material. d) a disseminação do conhecimento por intermédio dos materiais produzidos são mais efetivos quando acompanhados por cursos de capacitação de monitores e/ou guias. Ou seja, tal ação deve estar prevista em todas as atividades anteriormente mencionadas, seja na elaboração de roteiros ou na simples implantação de painéis e folhetos em áreas que permitem a sua realização, como municípios ou unidades de conservação. Estes cursos multiplicaram a informação geológica para a sociedade local, amplificando ainda mais dois dos objetivos principais do programa, que é a educação e conservação do patrimônio geológico.

De modo mais geral, fica claro que existe um amplo espaço para desenvolvimento dos projetos de geoturismo e divulgação do patrimônio geológico para a sociedade e que este espaço vem sendo ocupado pelos serviços geológicos e entidades afins de âmbito estadual. Os relatos apresentados demonstram esta tendência positiva. Acredita-se, pelas notícias que chegam a partir da participação nos diversos eventos realizados pelo país, que novos projetos estejam por despontar em breve. Por outro lado, o exemplo da Bahia demonstra a clara necessidade de que haja uma organização responsável pela implantação e manutenção dos painéis.

Observa-se, também, que as unidades de conservação são lugares especiais para a implantação deste tipo de sinalização, propiciando a divulgação da geodiversidade em conjunto com a biodiversidade.

Um aspecto a ser ainda mais discutido e considerado é que um projeto de sinalização sistemática possui um desdobramento muito maior do que a disponibilização de equipamentos de geoturismo. Ele também propicia a participação comunitária e certamente o desenvolvimento de projetos educacionais. Esta inserção necessita ser aproveitada ao máximo.

Por fim, considera-se, ainda, que o maior obstáculo a ser superado é a comunicação com a sociedade. Para tanto, precisa-se avançar no conhecimento sobre o usuário dos painéis interpretativos. É necessária, portanto, a realização de pesquisas sobre o público-alvo e planejamento prévio da interpretação, ou seja, deve-se melhorar cada vez mais a comunicação para despertar o interesse do usuário / visitante. 


\section{Referências bibliográficas}

ALVES, M.G. ; TEIXEIRA, S. ; MANSUR, K. L. Patrimônio Natural e Cultural de Campos dos Goytacazes. In: SIMPÓSIO DE GEOLOGIA DO SUDESTE, 11., 2009, São Pedro. Anais... São Paulo: SBG, 2009, CD-ROM, 1p.

BRILHA, J. Património Geológico e Geoconservação. A Conservação da Natureza na sua Vertente Geológica. Braga : Palimage Editores, . 2005. $190 \mathrm{p}$.

CARTER, J. (2001) A sense of place - an interpretive planning handbook. 2nd ed. Scottish Interpretation NetworkOnline:http://www.scotinterpnet.org.uk/fil e_download/3. Accessed 24 January 2010.CAMPANHA, G.A.C. 1991. Tectônica proterozóica no Alto e Médio Vale do Ribeira, Estados de São Paulo e Paraná. Tese de Doutorado. Instituto de Geociências, Universidade de São Paulo, 296 p.

CARVALHO, I. S.; GRECO, P.D.; MANSUR, K. L.; BARROSO, E.V.; MENDONÇA FILHO, J.G.; ALMEIDA, L.F.B. Rompendo Muros: a experiência do Museu da Geodiversidade da UFRJ. In: SIMPÓSIO DE GEOLOGIA DO SUDESTE, 11., 2009, São Pedro. Anais...São Paulo : SBG, 2009. v. 1. p. 116-116.

CENDRERO UCEDA, A. El Patrimonio Geológico. Ideas para su protección, conservación y utilización. In: MINISTERIO DE OBRAS PÚBLICAS, TRANSPORTES Y MEDIO AMBIENTE. ; SOCIEDAD ESPAÑOLA DE GEOLOGIA AMBIENTAL Y ORDENACIÓN DEL TERRITORIO; COMISSIÓN DE PATRIMONIO GEOLÓGICO DE LA SOCIEDAD GEOLÓGICA DE ESPAÑA (eds.). El patrimonio geológico: bases para su valoración, protección, conservación y utilización. 1996a. Madrid, 1996a. p. 17-27. Serie monografias.

CRÓSTA, A. P.; FURUIE, R.A.; SCHRANK, A.; VIEIRA, C.K. 2011. Astroblema de Vista Alegre, PR - Impacto meteorítico em derrames vulcânicos da Formação Serra Geral, Bacia do Paraná. In: WINGE, M.; SCHOBBENHAUS, C.; SOUZA, C.R.G.; FERNANDES, A.C.S.; BERBERT BORN, M. ; SALLUM FILHO, W. ; QUEIROZ, E. T. ; (Eds.). Sítios Geológicos e Paleontológicos do Brasil. Disponível em: <http://www.unb.br/ig/sigep/sitio044/sitio044.pdf> Acesso em 18/01/2011

DIAS, G., BRILHA J.B., ALVES, M.I.C., PEREIRA, D., FERREIRA, N., MEIRELES, C., PEREIRA, P., SIMÕES, P.P. (2003) Contribuição para a valorização e divulgação do património Geológico com recurso a painéis interpretativos: exemplos em áreas protegidas do NE de Portugal. Ciências da Terra (UNL), n. esp. p. 132$\begin{array}{llllllllllllll}1 & 3 & 5 & & \mathrm{D} & \mathrm{i} & \mathrm{s} & \mathrm{p} & \mathrm{o} & \mathrm{n} & \mathrm{i} & \mathrm{v} & \mathrm{e} & \text { । }\end{array}$ <http://repositorium.sdum.uminho.pt/bitstream/18 22/1256/1/cng_dias.>Acesso em: 24/01/2010.

DURANT, J. Participatory technology assessment and the democratic model of the public understanding of science. Science and Public Policy, 26 (5): 313-319, 1999.
EDER, W. F.; PATZAK, M. 2004. Geoparks- geological attractions: a tool for public education, recreation and sustainable economic development. Paris : UNESCO. Disponíve l e m : < http://www.episodes.co.in/www/backissues/273/1 62-164.pdf>. Acesso em: 06/10/2011.

FIGUEIREDO JR, A.G. RIBEIRO, G.P., SANTOS, R.A., VASCONCELOS, S.C., ALMEIDA, A.G. Placa informativa Caminhos Geológicos: processo de erosão marinha em Atafona, RJ. In: CONGRESSO BRASILEIRO DE GEOLOGIA, 42, CD-ROM, 2004, Araxá, 1p.

GARCIA-CORTÉS, A. \& URQUÍ, L. C. 2009. Documento metodológico para la elaboración del inventario Español de lugares de interés geológico (IELIG). Version 11, 12-03-2009. Instituto Geológico y Minero d e España. Disponível e m : <http://ww.wigme.es/internet./patrimonio>,. Acesso em: 23/03/2009.

GARCIA, R.A.N.; FARIA, T.T.; FALHEIRO, P.; FREITAS, A.C.A.; MANSUR, K. L.; NASCIMENTO, V.; SOARES, A.. Projeto Caminhos Geológicos na Internet: Software livre e interatividade para gestão do Patrimônio Geológico fluminense. In: CONGRESSO BRASILEIRO DE GEOLOGIA, 44., 2008, Curitiba. Anais... Curitiba: SBG, 2008. p. 406-406.

HOSE, T.A. Geotourism - Selling the Earth to Europe. In: Marinos PG, Koukis GC, Tsiambaos GC, and Stournaras GC (eds). Engineering Geology and the Environment.Rotterdam, 1997, p. 2955-2960.

HOSE, T.A. European 'Geotourism' - geological interpretation and geoconservation promotion for tourists. In: D. Barettino, W.A.P. Wimbledon \& E. Gallego (eds.). Geological Heritage: its conservation and management. Madrid, 2000. p. 127-146.

HOSE, T.A. (2008) Towards a history of Geotourism: definitions, antecedents and the future. In: BUREK, C. V. ; PROSSER, C. D. (eds). The History of Geoconservation. Geological Society. London, 2008. p. 37-60.

LEWENSTEIN, B.V. ; BROSSARD, D. Models of Public Understanding of Science. Draft Report. Cornell : Cornell University, 2005. 22p.

LICCARDO, A. ; PIEKARZ, G. F. ; SALAMUNI, E. Geoturismo em Curitiba. Curitiba : MINEROPAR, 2008. 122p.

LIMA, E. R.; ROCHA, A. J. D., SCHOBBENHAUS, C. . GEOSSIT: uma ferramenta para o inventário de geossítios. In: CONGRESSO BRASILEIRO DE GEOLOGIA, 46.,2012, Santos. Anais... Santos : SBG, 2012.

GEOTURISMO E GEOCONSERVAÇÃO. Disponível em: http://www.mineropar.pr.gov.br. Acesso em: jan.2013. 
MANSUR, K. L. Projetos Educacionais para a Popularização das Geociências e para a Geoconservação. Geologia USP, São Paulo, n. 5, p. 63-74, 2009a. Publicação Especial.

MANSUR, K. L. Caminhos de Darwin no Estado do Rio de Janeiro. Salto para o Futuro, v. 1, 7 p. 2009b D i s p o n íve I e m : $<$ http://www.tvbrasil.org.br/fotos/salto/series/1928 2316-CaminhosDarwin.pdf>. Acesso em: 25/04/2010.

MANSUR, K. L.; CARVALHO, I. S. Characterization and valuation of the geological heritage identified in the Peró dune field, State of Rio de Janeiro, Brazil. Geoheritage, v. 3, p. 97-115, 2011.

MANSUR, K.L.; CARVALHO, I.S.; DELPHIM, C.F.M.; BARROSO, E.V.O. Gnaisse Facoidal e a Cidade do Rio de Janeiro: um Caso Clássico de Paisagem Cultural. In: CONFERENCIA INTERNACIONAL "As Geociências no Desenvolvimento das Comunidades Lusófonas". Coimbra : Universidade de Coimbra, 2008. 4 p.

MANSUR, K. L.; FREITAS, P. L.; TALARICO, T. E.; CAPECHE, C. L.; GUEDES, E.; GUIMARÃES, P. V.; MEDEIROS, F. Projeto Caminhos Geológicos nas escolas: o caso de São José de Ubá - RJ. In: SIMPÓSIO DE GEOLOGIA DO SUDESTE, 11, 2005, Niterói. Anais... Niterói: SBG, 2005, p. 207.

MANSUR, K.L.; GHIZI, A.; GUEDES, E.; MEDEIROS, F.; NOGUEIRA, G.S.; BARBOSA, M.; NETTO, A.M.; RAGATKY, D.; GERALDES, M.; ZALAN, F.A. Transformação da Linguagem Científica em Popular na Elaboração de Placas Descritivas de Pontos de Interesse Geológico: O Caso do Geoparque do Vulcão de Nova Iguaçu-RJ. In: CONGRESSO BRASILEIRO DE GEOLOGIA, 42., 2004, Araxá. Anais... Araxá: SBG SBG, 2004.

MANSUR, K. L.; MELLO, C. L.; RAMOS, R.R.C.; NASCIMENTO, V.; NEGRÃO, A.P.; NOGUEIRA, G.S. O tombamento municipal de cinco geossítios de interesse científico e didático na Bacia Sedimentar de Volta Redonda (Rio de Janeiro). In: SIMPÓSIO DE GEOLOGIA DO SUDESTE, 11., 2009, São Pedro. Anais... São Paulo: SBG, 2009. v. 1. p. 137-137.

MANSUR, K. L.; NASCIMENTO, V. M. R. Disseminação do conhecimento geológico: metodologia aplicada ao Projeto Caminhos Geológicos. In: I SIMPÓSIO DE PESQUISA EM ENSINO E HISTÓRIA DE CIÊNCIAS DA TERRA, 1., 2007, Campinas; SIMPÓSIO NACIONAL SOBRE ENSINO DE GEOLOGIA NO BRASIL, 3., 2007, Campinas. Anais... Campinas: UNICAMP, 2007. $1 \mathrm{~cd}$ rom. Dis ponível e m : <http://www.ige.unicamp.br/simposioensino/artigo s/025.pdf >. Acesso em: 10/06/2008.

MANSUR, K.L.; SILVA, A.S. Society s Response: Assessment of the Performance of the Caminhos Geológicos ( Geological Paths ) Project, State of Rio de Janeiro, Brazil. Geoheritage, v. 3, 2011, p. 27-39.
MASSARANI, L.; MOREIRA, I. C. ; BRITO, F. Ciência e Público. Caminhos da divulgação científica no Brasil. Rio de Janeiro : Casa da Ciência,UFRJ, 2002. v. 1, 232p. Série Terra Incógnita.

MOREIRA, I. C. A inclusão social e a popularização da ciência e da tecnologia no Brasil. Inclusão Social. Revista IBICT, n. 1, p. 11-16, 2006. Disponível em: <http://revista.ibict.br/inclusao/index.php/inclusao /article/view/29/50>. Acesso em: 24/01/2010.

MOREIRA, I. C. ; BRITO, F. ; MANSUR, K. L. Darwin - um roteiro turístico, educacional e científico no estado do Rio de Janeiro, Brasil. SIMPÓSIO DE PESQUISA EM ENSINO E HISTÓRIA DE CIÊNCIAS DA TERRA, 2., 2009, São Paulo. Atas... São Paulo : Universidade de São Paulo, CD ROM.

MOREIRA, I. C. ; MASSARANI, L. Aspectos históricos da divulgação científica no Brasil. In: MASSARANI, L. ; MOREIRA, I. C. ; BRITO, F. (org.). Ciência e Público: caminhos da divulgação científica no Brasil. Rio de Janeiro : Casa da Ciência da UFRJ, 2002. p43-64.

NASCIMENTO, M.A.L.; MANSUR, K.L.; PIEKARZ, G.; PEDREIRA, A.J.; RIBEIRO, R.R. Divulgação do Patrimônio Geológico por meio de Sinalização Geoturística. In: XXIII Simpósio de Geologia do Nordeste, 2009, Fortaleza. XXIII Simpósio de Geologia do Nordeste, 2009. p. 225-225.

NASCIMENTO, V.; PIMENTA, T. S.; MANSUR, K. L. Praia Preta na llha Grande, Angra dos Reis - RJ: A desconstrução didática de uma praia. In: CONGRESSO BRASILEIRO DE GEOLOGIA, 44., 2008, Curitiba. Anais... Curitiba:SBG, 2008. p. 404-404.

NAVAS, A. M. Concepções de popularização da ciência e da tecnologia no discurso político: impactos nos museus de ciências. f. Dissertação (mestrado em ...) - Faculdade de Educação da Universidade de São Paulo, São Paulo 2008.

NAVAS, A.M., CONTIER, D., MARANDINO, M. (2007) Controvérsia Científica comunicação Pública da Ciência e Museus no Bojo do Movimento CTS. Ciência \& Ensino, Número especial 1. Online. Disponível em: $<$ http://www.ige.unicamp.br/ojs/index.php/ciencia eensino/article/view/127/102>Acesso em: 24/01/2010.

PIEKARZ, G. F. Geoturismo no Karst. Curitiba : MINEROPAR, 2011. 121p, PIEKARZ, G. F. ; LICCARDO, A. Turismo Geológico na Rota dos Tropeiros, Paraná. Revista Global Tourism, v.3, n.2, p. 01-18, 2007.

PIEKARZ, G.F.; SALAMUNI, E.; CRÓSTA, A.P.; LICCARDO, A.; GUIMARÃES, G.B. Tombamento e geoconservação experiência paranaense. In:CONGRESSO BRASILEIRO DE GEOLOGIA, 46.,2012, Santos. Anais... Santos: SBG, 2012. $p$. 
ROCHA-CAMPOS A. C. Varvito de Itu, SP - Registro clássico da glaciação neopaleozóica. In: SCHOBBENHAUS, C.; CAMPOS D.A.; QUEIROZ E.T.; WINGE M.; BERBERT-BORN, M. L. C. (Eds). Sítios Geológicos e Paleontológicos do Brasil. Brasília : DNPM/CPRM/SIGEP, 2002a. v. 1, p. 147-154.

SCHOBBENHAUS, C. ; CAMPOS, D. A. ; QUEIROZ, E. T. ; WINGE, M. ; BERBERT-BORN, M. L. C. (Eds). Sítios Geológicos e Paleontológicos do Brasil. Brasília : DNPM/CPRM/SIGEP, 2002b. v. 1, p. 155-159.

RUCHKYS, U. A. ; MACHADO, M. M. M. ; CASTRO, P. T. A.; RENGER, F. E.;TREVISOL, A.; BEATO, D. A. C. 2012. Geoparque Quadrilátero Ferrífero (MG)-Proposta. In: SCHOBBENHAUS, C.; SILVA, C. R. (Org.). Geoparques do Brasil-Propostas. Rio de Janeiro : Serviço Geológico do Brasil-CPRM, 2012. v. 1, p. 183-220, 2012.

SÃO PAULO. Decreto Estadual no 11.138, de 3 fevereiro de 1978. Dispõe sobre a organização da Secretaria de Estado dos Negócios da Agricultura e dá providências correlatas. Diário Oficial do Estado de São Paulo, São Paulo SP, 15/fev.1978, Seção 1, p. 36.

SÃO PAULO. Decreto Estadual no 24.931, de 20 de março de 1986. Reorganiza o Instituto Geológico, da Coordenadoria da Pesquisa de Recursos Naturais, da Secretaria de Agricultura e Abastecimento, e dá providências correlatas. Diário Oficial do Estado de São Paulo, São Paulo, 20 mar.1986.

SÃO PAULO. Decreto Estadual no 26.942, de 01 de abril de 1987. Dispõe sobre a transferência e a vinculação de órgãos e entidades à Secretaria do Meio Ambiente. Diário Oficial do Estado de São Paulo, São Paulo, 01 abr. 1987.

SÃO PAULO. Resolução no 76, de 05 de novembro de 2009. Dispõe sobre a criação do Conselho Estadual de Monumentos Geológicos. Secretaria de Estado do Meio Ambiente. Diário Oficial de São Paulo São Paulo, 05 nov. 2009. Seção 1, p. 42.

SCHMITT, R. S. ; MANSUR, K. L. ; TUPINAMBA, M. ; VALERIANO, C. M. ; RAGATKY, D. O Projeto Caminhos Geológicos - Divulgação Científica dos Monumentos Geológicos do Estado do Rio de Janeiro. In: CONGRESSO BRASILEIRO DE EXTENSÃO UNIVERSITÁRIA, 2., 2004, Belo Horizonte. Anais... Belo Horizonte, 2004.

SCHMITT, R. S. ; MANSUR, K. L. Projeto Caminhos Geológicos. Niterói:DRM, 2000. 11p.
SCHMITT, R. S. ; MANSUR, K. L. ; MONTEIRO, M. C. Contribuição geológica para o tombamento de duas áreas no município de Armação dos Búzios como patrimônio histórico-cultural do Estado do Rio de Janeiro. In: CONGRESSO BRASILEIRO DE GEOLOGIA, 42, 2004, Araxá. Anais... Araxá: SBG, 2004, CD-ROM.

SCHOBBENHAUS, C. ; CAMPOS, D. A.,QUEIROZ, E. T.; WINGE, M. ; BERBERT-BORN, M. L. (Ed.). Sítios geológicos e paleontológicos do Brasil. Brasília : DNPM, CPRM, SIGEP, 2002. $540 \mathrm{p}$.

SCHOBBENHAUS, C.; SILVA, C. R. (Org.). Geoparques do Brasil-Propostas. Serviço Geológico do Brasil-CPRM, 2012, v. 1, 745 p.

TALARICO, T. E. Se esse Rio fosse meu.... Caderno Interativo de Educação Ambiental. Rio de Janeiro : Embrapa Solos, 2004. 54 p. (Ensino Fundamental Ciclos I e II).

TALARICO, T. E. ; FREITAS, P. L. ; CAPECHE, C. L.; MANZATTO, C. V.; FIDALGO, E. C. C. ; SILVA JUNIOR, G. C. ; MENEZES, J.; MANSUR, K. L. ; SILVA, L. P. ; PRADO, R. B. ; FERRAZ, R. P. D. Minha terra, meu futuro: Educação Ambiental: Ensino Fundamental. Rio de Janeiro : Embrapa Solos, 2005, 104 p.

UNESCO. Guidelines and criteria for national geoparks seeking UNESCO's assistance to jointhe Global Geoparks Network April 2010. Disponível em: <http://www.globalgeopark.org/UploadFiles/2012_ 9_6/GGN2010.pdf>Acesso em: 05.03. 2013.

VALERIANO, C. M. Divulgação geocientífica através do Projeto Caminhos Geológicos: o caso do painel explicativo sobre o Pão de Açúcar. In: CONGRESSO BRASILEIRO DE GEOLOGIA, 43, 2006, Aracaju, Anais...Aracaju : SBG/Núcleo BA-SE, 2006. p. 261261.

WINGE, M.; SCHOBBENHAUS, C.; SOUZA, C. R. G.; FERNANDES, A. C. S.; BERBERT-BORN, M. L.; QUEIROZ, E. T.; CAMPOS, D. A. (Eds.). Sítios geológicos e paleontológicos do Brasil. Brasília : CPRM, 2009. v. 2, 515 p.

WINGE, M.; SCHOBBENHAUS, C.; SOUZA, C.R. G.; FERNANDES, A.C.S.; BERBERT-BORN, M.L.; SALLUN FILHO, W.; QUEIROZ, E.T. (Ed.). Sítios geológicos e paleontológicos do Brasil. Brasília : CPRM, v. 3 (no prelo).

ZAINE, M.F.; PERINOTTO, J.A.J. Patrimônio natural e história geológica da região de Rio Claro/SP. Rio Claro : Arquivo Público e Histórico do município de Rio Claro, 1996, 91p. 